\title{
Nanoparticles for the Treatment of Inner Ear Infections
}

\author{
Dan Cristian Gheorghe ${ }^{1,2}$, Adelina-Gabriela Niculescu ${ }^{3}\left(\mathbb{D}\right.$, Alexandra Cătălina Bîrcă ${ }^{4}$ and \\ Alexandru Mihai Grumezescu $4,5, *$ (D) \\ 1 "Carol Davila" University of Medicine and Pharmacy, 050474 Bucharest, Romania; \\ gheorghe.dancristian@gmail.com \\ 2 "M.S. Curie" Clinical Emergency Hospital for Children, 050474 Bucharest, Romania \\ 3 Faculty of Engineering in Foreign Languages, University Politehnica of Bucharest, \\ 060042 Bucharest, Romania; niculescu.adelina19@gmail.com \\ 4 Faculty of Applied Chemistry and Materials Science, University Politehnica of Bucharest, \\ 060042 Bucharest, Romania; ada_birca@yahoo.com \\ 5 Research Institute of the University of Bucharest-ICUB, University of Bucharest, 050657 Bucharest, Romania \\ * Correspondence: agrumezescu@upb.com; Tel.: +40-21-402-3997
}

check for updates

Citation: Gheorghe, D.C.; Niculescu, A.-G.; Bîrcă, A.C.; Grumezescu, A.M. Nanoparticles for the Treatment of Inner Ear Infections. Nanomaterials 2021, 11, 0. https://doi.org/

\section{Academic Editors:}

Miguel Gisbert-Garzarán and María Vallet-Regí

Received: 15 April 2021

Accepted: 13 May 2021

Published: 16 May 2021

Publisher's Note: MDPI stays neutral with regard to jurisdictional claims in published maps and institutional affiliations.

\begin{abstract}
The inner ear is sensitive to various infections of viral, bacterial, or fungal origin, which, if left untreated, may lead to hearing loss or progress through the temporal bone and cause intracranial infectious complications. Due to its isolated location, the inner ear is difficult to treat, imposing an acute need for improving current therapeutic approaches. A solution for enhancing antimicrobial treatment performance is the use of nanoparticles. Different inorganic, lipidic, and polymericbased such particles have been designed, tested, and proven successful in the controlled delivery of medication, improving drug internalization by the targeted cells while reducing the systemic side effects. This paper makes a general presentation of common inner ear infections and therapeutics administration routes, further focusing on newly developed nanoparticle-mediated treatments.
\end{abstract}

Keywords: inner ear; infections treatment; antimicrobial nanoparticles; drug-delivery systems; potential side effects

\section{Introduction}

Inner ear disorders affect an important portion of the world population, deafness being the most common sensory impairment worldwide [1-3]. A significant share of this burden is caused by sensorineural hearing loss (SNHL), originating from cochlear defects [3]. Some of these defects have been reportedly caused by various congenital and acquired inner ear infections [4-8].

Hence, ear disorders' prevalence represents an acute incentive and opportunity towards improving therapeutic interventions $[9,10]$. Specifically, the small size, limited accessibility, and high vulnerability of the inner ear pose certain difficulties, narrowing down treatment options [11]. Currently used methods, such as systemic delivery, intratympanic injection, and direct inner ear drug delivery, often face challenges in terms of efficacy and invasiveness [1,9].

The anatomical and physiological barriers of the ear coupled with the low long-term stability of drug molecules are the main factors that hinder drug penetration and permeation, resulting in sub-therapeutic concentrations at the required site [12]. To overcome the issues of conventional drug-administration, nanotechnology is receiving increasing attention in the field of auditory science [13]. Particularly, nanoparticle-based systems have been proven advantageous in controlled and targeted drug-release, protecting pharmacological formulations up to the desired site, facilitating transmembrane transport, increasing cell uptake, and reducing required doses and side-effects [14].

In this respect, the present paper aims to describe the most common inner ear infections, the causes behind these affections, and current medication administration routes. 
Moreover, the newest advancements in nanoparticle-mediated treatments are presented in detail, with a special focus on their safety and efficacy.

\section{Inner Ear Infections}

The inner ear is sensitive to infections that may produce permanent SNHL and vestibular dysfunction $[15,16]$. One criterion for distinguishing between different inner ear infections concerns the affected structures. From this point of view, there are two main possibilities: labyrinthitis and vestibular neuronitis [17].

As its name implies, labyrinthitis is an infection located in the membranous labyrinth. This structure is usually affected by bacterial translocation into the inner ear [17], causing vertigo, nausea, vomiting, tinnitus, and even hearing impairment or hearing loss [18]. The inflammation can result through two different mechanisms. Inflammation can be a secondary manifestation caused by bacterial toxins and/or host cytokines and inflammatory mediators, producing serous labyrinthitis; or it can be caused directly by the bacteria, leading to suppurative labyrinthitis [18]. Particularly, the latter form of labyrinthitis can have severe complications; due to the proximity to the central nervous system, it can progress to intracranial infectious complications, requiring prompt treatment $[15,17,19]$.

Vestibular neuronitis (or neuritis) is often used as a synonym for labyrinthitis, being usually assimilated as a viral infection rather than bacterial $[17,20]$. However, this term can only be used when just the vestibular portion of the eighth cranial nerve is involved $[18,20]$. This infection results in a sudden unilateral loss of peripheral vestibular function manifested in the acute phase through prolonged rotational vertigo, nausea, vomiting, postural imbalance, and spontaneous nystagmus [21,22]. As the cause is ultimately due to a virus, this infection's management is symptomatic [17].

Inner ear infections can also be classified depending on their causing pathogen. In this respect, three categories can be distinguished: viral, bacterial, and fungal infections (Figure 1).

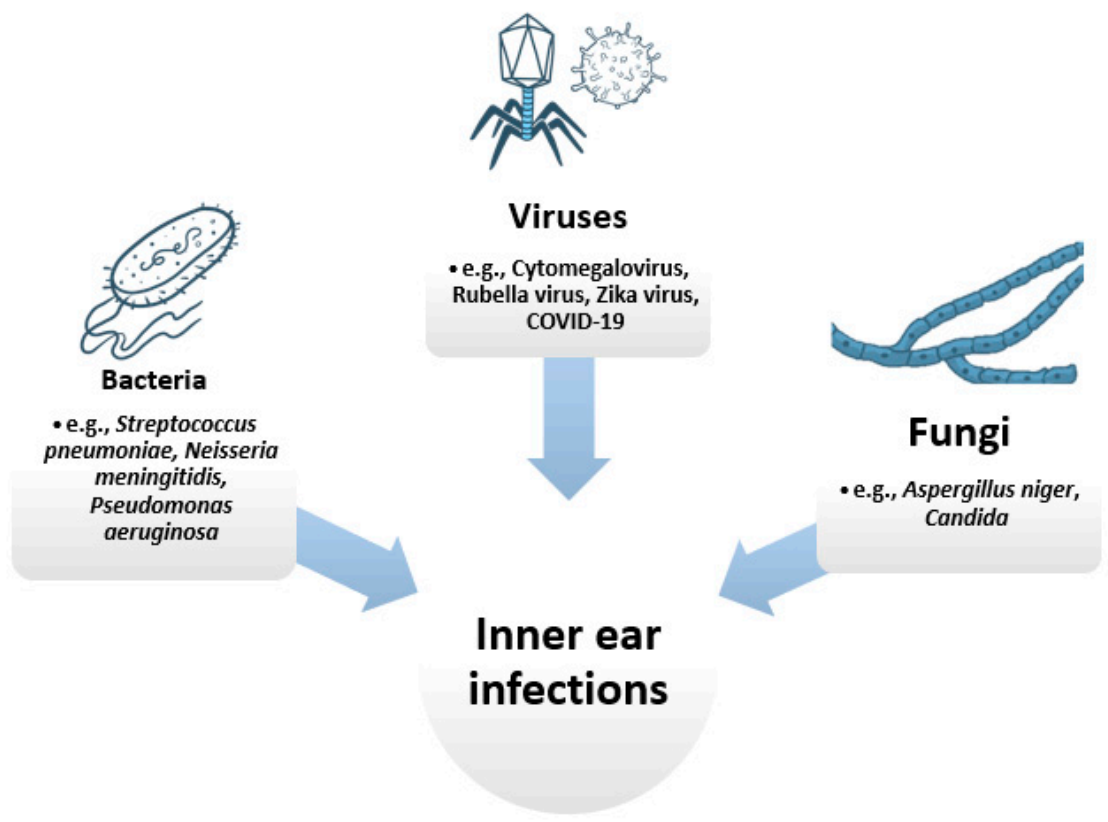

Figure 1. Main categories of pathogens causing inner ear infections. Created based on information from literature References [23-30].

\subsection{Viral Infections}

Viral infections are assumed to play a direct or indirect role in the causation of several inner ear disorders [31]. Viruses can either directly affect inner ear structures; they can induce inflammation that further produces damages; or they can increase the susceptibility to bacterial or fungal infections, eventually leading to hearing loss [26]. 
Several viral infections that can be congenitally acquired can produce SNHL [32]. A leading cause of non-inherited SNHL is congenital cytomegalovirus infection [27,33-35]. This DNA virus is a member of the Herpesviridae family and is widely spread in the community. Subclinical infection with cytomegalovirus can affect all bodily organs, including the middle and the inner ear [36]. When an inner ear infection occurs, the marginal cell layer of the stria vascularis is always infected, followed by infection progression into the Reissner's membrane [27]. This further leads to alteration of sensory structures by dysregulation in ion homeostasis, particularly in the potassium circulation [37].

Rubella (or German measles) is a contagious viral infection that most frequently occurs in the fetus during pregnancy, being one of the most common causes of hearing loss in newborns. During the sixth to twelve weeks of pregnancy, the inner ear was reported to be most susceptible to damage. SNHL in babies infected with the Rubella virus is associated with hemorrhagic damage of the organ of Corti. Interruption in further development of different parts of the inner ear and auditory nerve is also reported [15,28,38,39].

A relation between Zika virus infection and hearing loss was also reported in both infants and adults. Zika virus was found to produce a graded distribution of cellular damage in the cochlea, with the greatest damage in the apex, in a manner similar to cytomegalovirus infection [32,40,41].

Recently, it has been noticed that COVID-19 infection could have deleterious effects on the hair cells of the cochlea, despite being asymptomatic. However, further research is needed for properly understanding the mechanism of these effects [26,42,43].

\subsection{Bacterial Infections}

SNHL can also result as a complication and sequela of bacterial infections, such as meningitis [29,44]. The most common causes of bacterial meningitis in the first 90 days of life are Group B Streptococcus and Escherichia coli, while, in children, SNHL is more frequently associated with meningitis caused by Streptococcus pneumoniae or Neisseria meningitidis [29]. The released inflammation by-products (e.g., nitric oxide, superoxide, peroxynitrite) contribute to the disruption of the blood labyrinth barrier, inducing a cytotoxic effect on the cochlea. The inner ear can also be damaged through vascular occlusion, which may further lead to cochlear hypoxia and ischemia, and neural damage [44].

Another bacterial infection is otitis media. Generally caused by microorganisms like Pseudomonas aeruginosa, Staphylococcus aureus, Proteus mirabilis, Klebsiella pneumonia and Escherichia coli, this infection is mainly located in the middle ear $[45,46]$. Out of the enumerated pathogens, Pseudomonas aeruginosa is one of the most common bacteria to produce chronic suppurative otitis media and reach perilymph by entering through the round window $[30,47]$. Moreover, recurring otitis media can destroy ear structures such as small bones, seventh cranial nerve or inner ear, leading to permanent hearing loss [45].

\subsection{Fungal Infections}

Compared to other infection sources, fungal infections of the inner ear have only rarely been reported [48]. These pathogens usually affect the auditory canal and middle ear arc, often being regarded as harmless saprophytic growth [49]. However, in immunocompromised individuals or patients undergoing long-term antibiotic treatment, such infections may become clinically significant and extend to inner structures [48,49]. Other factors in otomycotic infection progression are humidity, moisture, bathing, and self-hygiene. In swimmers and divers, the external ear canal and tympanic membrane can be infected, and, because of water pressure, pathogens can reach further to the middle and inner ear. The main pathogens responsible for otomycosis are Aspergillus niger and Candida [25,50].

\section{Administration Routes}

Inner ear infections are challenging to treat due to their isolated location. Placed in the temporal bone, the inner ear is protected by many anatomical and physiological barriers, which hinder therapeutics' delivery (Figure 2) [14,51-56]. 


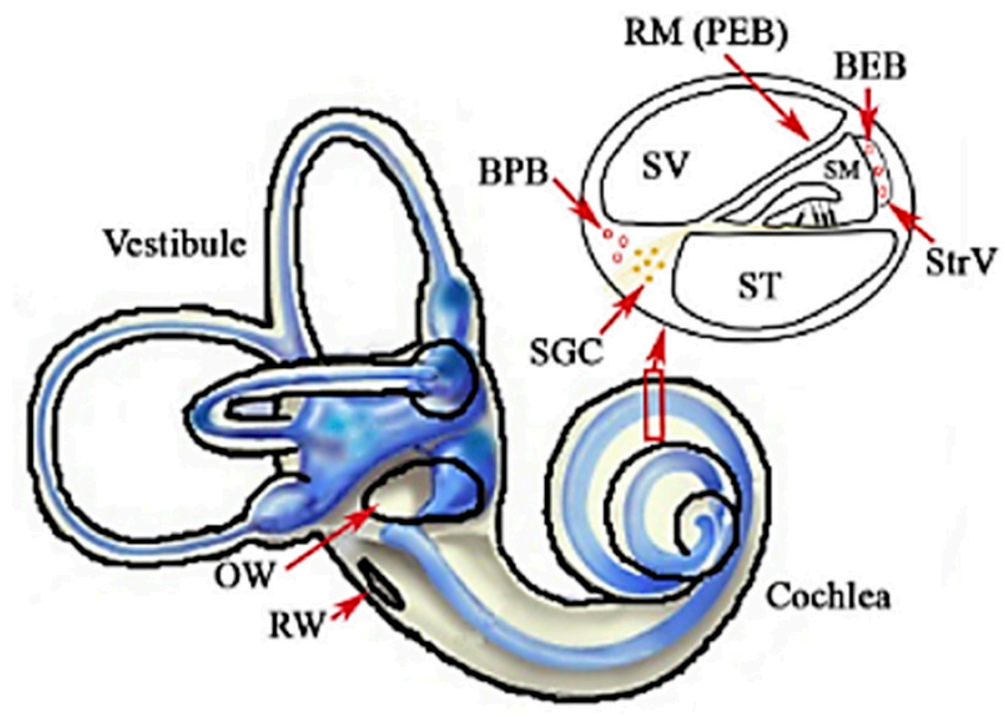

Figure 2. Inner ear barriers: middle-inner ear barriers— the oval window (OW) and the round window (RW); blood-inner ear barriers: the blood-endolymph barrier (BEB) and the blood-perilymph barrier (BPB); the perilymph-endolymph barrier (PEB)—Reissner's membrane (RM). Other abbreviations: SGC—spiral ganglion cell; SM—scala media; ST—scala tympani; StrV—stria vascularis; SV—scala vestibuli. Reprinted from an open-access source [57].

When the inner ear gets infected, aggressive treatment is required to try to prevent complete and permanent loss of cochleovestibular function and avoid spreading the infection to intracranial structures. Generally, the treatment includes administering anti-infective and anti-inflammatory medications, surgical intervention for draining abscesses, and supportive care for the associated symptoms $[10,15]$. Nonetheless, the treatment's efficacy and safety are highly dependent on inner ear drug delivery systems [58].

Nowadays, the first-line approach for treating inner ear disorders is the systemic delivery of medication $[10,12]$. It involves the oral, intravenous, or intramuscular administration of therapeutics that are further distributed throughout the entire organism, despite being needed only in a small body part $[9,12]$. This administration route has two main drawbacks: it leads to systemic side effects and limits the drug concentration reaching the target site [9]. To avoid these issues, local drug delivery started to be utilized as an alternative [10].

The most commonly used local administration method is intratympanic drug injection [59-61]. When using this technique, the drug enters the middle ear cavity and must remain there for a sufficient time to pass through the round or oval window and reach the inner ear [61-63]. This administration route allows higher concentrations of medicines at the target site without metabolism "first-pass" [11]. However, drugs do not always stay in contact long enough with the two windows and are discharged to the Eustachian tube before reaching the inner ear in sufficient amount [62].

Another approach is to deliver the necessary drugs directly into the inner ear cavity. The method supposes passing a needle through either the round window or oval window and discharging the drug load into the cochlea or vestibule, respectively [58]. Alternatively, the drug can be released by a cochlear implant [64-67], osmotic mini-pumps [68-71], or through reciprocating perfusion systems [72-74]. This technique significantly increases drug bioavailability in the inner ear, having the highest efficiency among all administration possibilities [61]. Nonetheless, this is a highly invasive approach, requiring surgical intervention [51].

A comparison of the inner ear administration routes is provided in Figure 3. 


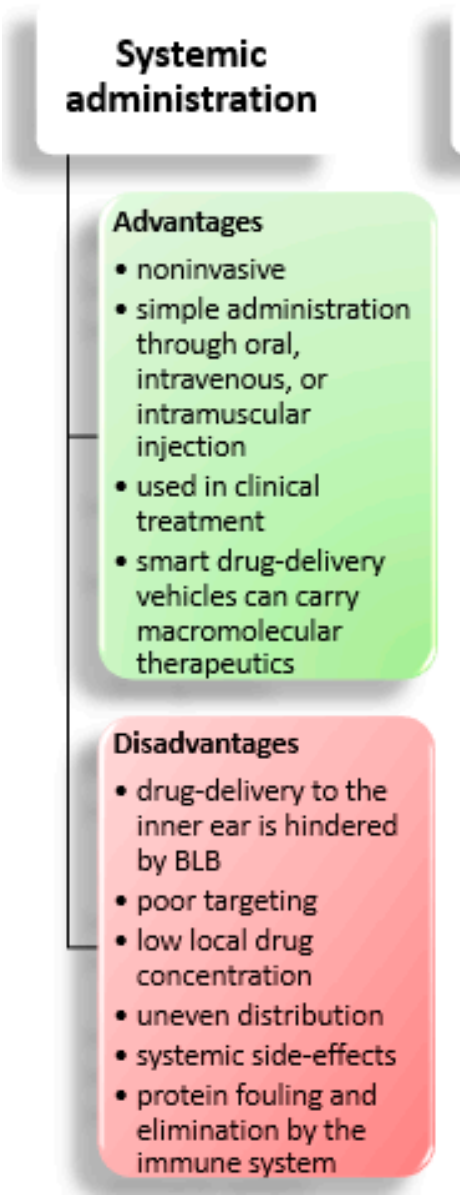

\section{Middle ear intratympanic administration}

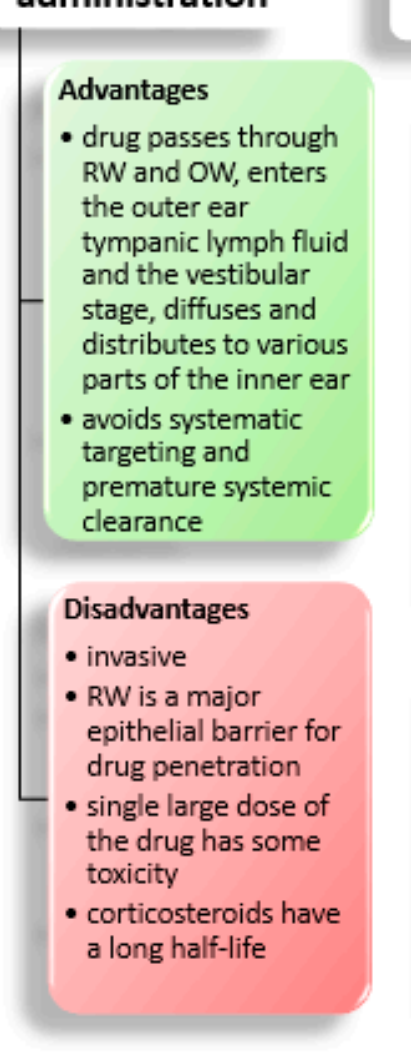

\section{Direct inner-ear drug delivery (RW an OW routes)}

\begin{tabular}{|l} 
Advantages \\
- low dose direct \\
administration \\
- easier to reach the \\
target than by \\
systemic or middle ear \\
intratympanic \\
administration \\
- avoids systematic \\
targeting and \\
premature clearance \\
- RW is the mainstream \\
drug-delivery route for \\
the inner ear \\
Disadvantages \\
- highly invasive \\
- requires surgical \\
access to cochlea \\
- poses risks of trauma \\
and postoperative \\
complications (e.g., \\
protein fouling, \\
inflammation)
\end{tabular}

Vestibular drug delivery (semicircular canal injection)

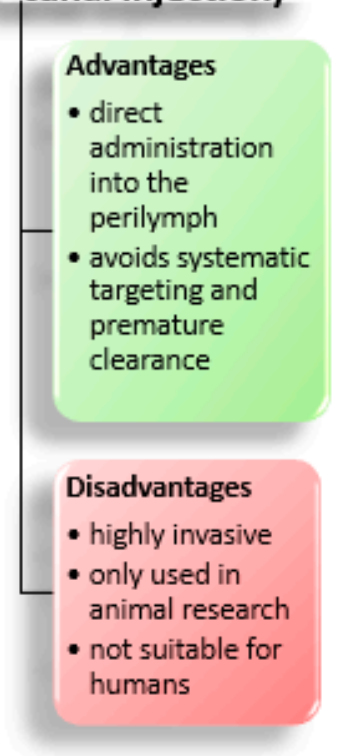

Figure 3. Comparison of different inner ear administration routes. Abbreviations: BLB—blood-labyrinth barrier, RW—round window, OW—oval window. Created based on information from literature References $[14,51,54,56,75]$.

\section{Nanoparticles-Mediated Treatment}

Other delivery approaches had to be explored to overcome the limitations of traditional drug administration methods [14,76]. Various inner ear delivery systems (e.g., solid foams, hydrogels, nanoscale structures) are investigated to improve local effectiveness and reduce systemic adverse effects [11,77].

One of the most promising solutions is to include nanoparticles (NPs) in the therapeutic strategy $[1,13]$. Their small sizes $(<1 \mu \mathrm{m})$ coupled with their inherent physical, chemical, and biological properties render nanoparticulate systems suitable for crossing barriers and efficiently treat inner ear infectious disorders [9,12,55]. In recent years, rather than simply investigating their permeation into the inner ear, research was focused on loading drugs into/onto NPs and transferring them to the inner ear to observe functional changes [62].

Delivering medication via NPs is considered advantageous, especially in terms of drug stabilization for controlled release and surface modification for specific targeting $[12,58,78,79]$. After administration into the middle ear, loaded-NPs diffuse through the round window membrane, facilitating the freed-drug passage into the cochlea $[9,77]$. NPs compensate drug properties in terms of low solubility, degradation, and short half-life, this approach reportedly leading to improved transmembrane transport, increased uptake and internalization of drugs by targeted cells (e.g., hair cells, spiral ganglion neurons, pathogen entities), reduced required doses, and subsequent diminished side effects $[14,55,62,80,81]$.

To achieve such results, various NP-based delivery systems are under development (Figure 4) [1]. Inorganic, lipid, and polymeric materials can be employed to fabricate nanocarriers for hydrophilic and/or hydrophobic drugs to be released in a targeted and controlled manner [12,77,80-82]. 
(a)

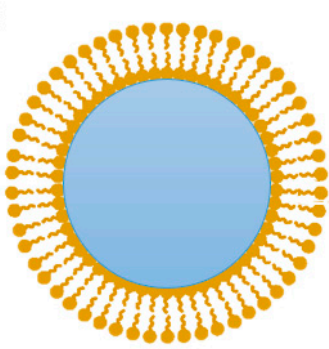

(d)

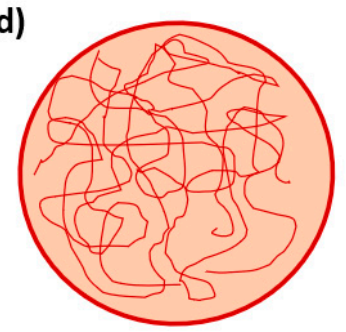

(b)

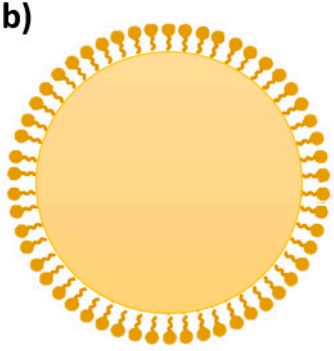

(e)

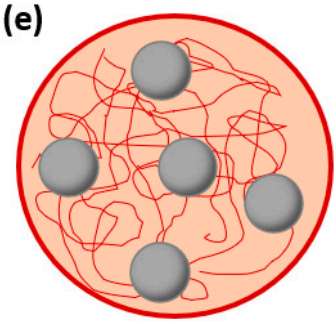

(c)

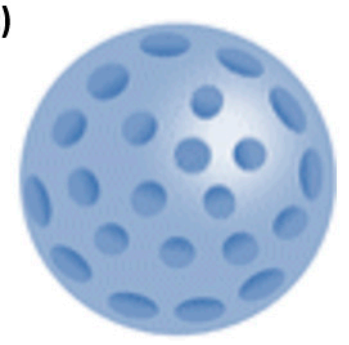

(f)

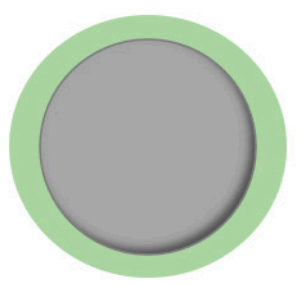

Figure 4. Schematic representation of various nanoparticles: (a) liposome; (b) lipid core nanoparticle; (c) ceramic nanoparticle; (d) polymeric nanoparticle; (e) superparamagnetic iron oxide NP (SPION)loaded polymeric nanoparticle; (f) coated SPION. Created based on information from literature References [11-13,51,83-85].

\subsection{Inorganic Nanoparticles}

Metal-based NPs with inherent antimicrobial activity are one of the most extensively researched materials $[83,86]$. Silver nanoparticles (AgNPs) are of special interest against infections, exhibiting strong activities in antibacterial, antiviral, and antifungal studies [87-91]. AgNPs can physically interact with various bacterial cells' surface, damage the cell membranes, and produce structural changes that render these pathogens more permeable [89]. Specifically, AgNPs can reach the inner ear in a dose-dependent manner after intratympanic administration and destroy pathogens either alone or in combination with various antibiotic formulations $[89,92]$. This is a highly advantageous ability against multi-drug resistant bacteria, such as $P$. aeruginosa, overcoming the drawbacks of free antibiotics and eliminating the microorganisms with high efficacy in the ear therapy [87].

Gold nanoparticles (AuNPs) can also carry hydrophilic and hydrophobic molecules, being also researched for imaging applications $[93,94]$. There are no studies in the literature on AuNPs delivery to the inner ear yet [95], but these nanoparticles have been tested as candidates for inner ear contrast agents [96]. Despite not obtaining a significant imaging enhancement, the study reported successful localization of AuNPs in cochlear cells, which is an encouraging result for future tests. Besides, biomolecules, polymers, and proteins can be used to improve the therapeutic properties of AuNPs, such as their biocompatibility, biodistribution, stability, and half-life [93]. For instance, AuNPs functionalized with 5fluorouracil showed bactericidal effects against Gram-negative bacteria and antifungal activity against Aspergillus fumigates and Aspergillus niger [97]. Therefore, it can be expected that combinations of AuNPs and other substances would soon be developed for inner ear drug delivery platforms.

Superparamagnetic iron oxide nanoparticles (SPIONs) are another promising strategy as they can be magnetically guided across the round window and precisely reach the targeted inner ear structures [13,56,59]. Moreover, their relatively simple synthesis, low toxicity, intrinsic antimicrobial activity, and functionalization ability are very important properties for designing effective biocompatible nanoplatforms [98]. SPIONs cannot encapsulate any substance, but they can be loaded into polymeric nanoparticles or coated with the needed drug. For inner ear drug delivery, SPIONs have been tested in combination with PLGA, chitosan, silica, and dextran $[13,51,56]$. Such nanocomposites can significantly 
enhance antibiotics' activity against both Gram-positive and Gram-negative bacteria, being a helpful tool in treating multi-drug resistant pathogen strains infections [99-101].

Other metal-oxide based NPs that have been proven effective against inner earrelated infectious diseases are titanium dioxide (photocatalytic effect against fungi and bacteria) [90], zinc oxide (strong antimicrobial activity against Staphylococcus aureus, Escherichia coli, Klebsiella pneumoniae, and Pseudomonas aeruginosa; anti-Candida albicans properties) [102,103], aluminum oxide (strong growth-inhibitory effect on E. coli) [104], silver oxide (reasonable bactericidal activity against E. coli, P. aeruginosa, and S. aureus) [104], copper oxide (anti-C. albicans properties) [103], calcium oxide (bactericidal activity against E. coli and S. aureus) [97], zirconium oxide (potential inhibitory action against $P$. aeruginosa and S. aureus and good inhibition against E. coli) [105].

Silica nanoparticles are also attractive for carrying medicine due to their commercial availability, narrow particle size distribution, and biodegradability under physiological conditions [106,107]. Particularly, mesoporous silica nanoparticles (MSNs) can be employed to manufacture controlled-release antimicrobial platforms by encapsulating antibiotics within their pores $[108,109]$. Moreover, MSNs are relatively easy to functionalize, their surface modification improving the colloidal stability and targeting ability towards desired cells/tissues $[13,110,111]$. Nanoporous silica nanoparticles can also be used in treating inner ear diseases. They can target spiral ganglion neurons, being loaded with a brain-derived neurotrophic factor that is released in the long term [112].

Silicon carbide nanoparticles (SiC NPs) are inert antibacterial, hemocompatible, biocompatible, and non-toxic ceramic NPs that have been recently researched for biomedical applications $[113,114]$. SiC NPs were proven to enhance the antimicrobial activity of other materials when used as additives, showing improved in vitro results against $E$. coli and $S$. aureus [115]. Other ceramic nanoparticles of interest against inner ear-related pathogens are lithium niobate $\left(\mathrm{LiNbO}_{3}\right)$ [1], silicon nitride $\left(\mathrm{Si}_{3} \mathrm{~N}_{4}\right)$ [116], titanium carbide (TiC) [117], and barium titanate $\left(\mathrm{BaTiO}_{3}\right)$ [118].

\subsection{Lipid Nanoparticles}

Different lipid NPs have also been tested as delivery systems to the inner ear [77]. Formulations employing lipid core nanocapsules (LCNs), solid lipid NPs (SLNs), and phospholipid-based NPs are considered attractive due to their biodegradability and ability to deliver hydrophilic and/or lipophilic drugs [77,82].

Lipid core nanocapsules consist of a lipidic core made of triglycerides and mineral oils, with a surrounding shell of lecithin, polyethylene glycol, or poloxamers as stabilizing agents $[13,55,119]$. The LCNs' structure can be modified to include various hydrophobic drugs and control their release kinetics $[13,55]$. Studies have shown promising results concerning LCNs permeation through the round window membrane and distribution throughout human inner ear cell populations [119], proving these particles' potential in treating inner ear infections.

Solid lipid nanoparticles are also researched for delivering drugs to the inner ear [120]. SLNs are sub-micron colloidal carriers with unique properties, such as high drug loading and interaction of phases at the interfaces, which render them attractive for improving pharmaceuticals performance $[121,122]$. SLNs are reported to be a better alternative to liquid systems, as they form biocompatible and biodegradable lipids that are solid at body temperature, leading to improved control over drug delivery [77]. SLNs encapsulate the drug, improve its stability, and increase in vivo bioavailability, the delivery system exhibiting protective effects on the cochlea [123]. As a novel alternative to antibiotics, SLNs loaded with antibacterial oligonucleotide therapeutics have been investigated against $E$. coli, with promising results [124].

Phospholipid-based NPs are advantageous structures as they can encapsulate hydrophobic molecules in their phospholipid layer and hydrophilic molecules in their aqueous core. Due to their similarity with plasma membranes, amphiphilic liposomes can transport their load across the round window membrane and deliver it inside the targeted 
cells $[13,56,125]$. Moreover, liposomes allow surface modification with various chemical and biological entities, such as polyethylene glycol, antibodies, peptides, carbohydrates, chitosan, hyaluronic acid, and folic acid, leading to multifunctional nanoparticles [13,55] (Figure 5).
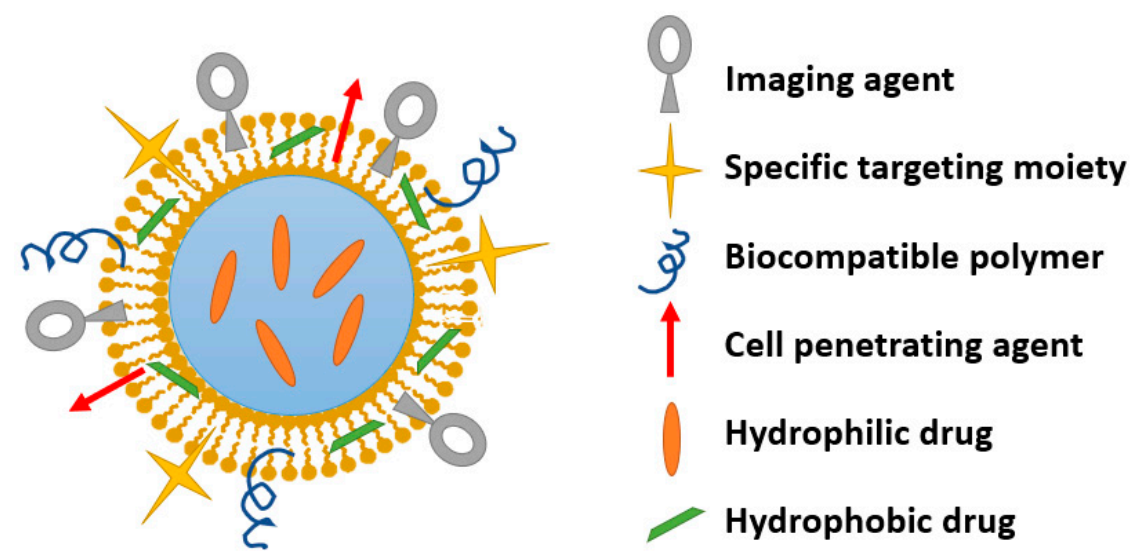

Figure 5. Schematic representation of a multifunctional nanoparticle. Created based on information from literature References [125-128].

\subsection{Polymeric Nanoparticles}

The variety and versatility of polymers have also attracted interest towards developing nanoplatforms for infection treatment. Several polymeric nanostructures have been shown effective as antimicrobials against ear-related pathogens, such as E. coli, P. aeruginosa, S. aureus, K. pneumonia, and C. albicans [129]. Nonetheless, polymers are most frequently studied as drug carriers.

One of the most extensively researched polymers is poly (lactic-co-glycolic acid) (PLGA), a Food and Drug Administration (FDA) and European Medicines Agency (EMA)approved biodegradable copolymer that can encapsulate diverse molecules (e.g., proteins, steroids, antibiotics, nucleic acids) [55]. Due to their ability to adapt to specific requirements concerning drug properties and target tissue, PLGA NPs have a great potential in local inner ear delivery $[55,56]$. For instance, it has been demonstrated that rhodamine-loaded PLGA NPs can permeate through the round window membrane when applied locally, leading to a higher cochlear uptake than by systemic administration [56]. Moreover, functionalization with hydrophilic surface molecules has been proved to enhance permeability and successfully deliver rhodamine, SPIONs, and steroids in the inner ear, both in animal and human models [82].

Chitosan is another non-toxic, safe, and biodegradable polymer that can help increase the efficiency of inner ear disease treatment $[79,125,130,131]$. In addition to its antibacterial and antifungal activity [132,133], chitosan has a great potential in delivering therapeutics in a controlled and sustained manner from the middle ear to the inner ear without altering inner ear structures [134]. Besides, engineered fluorescence traceable chitosan NPs were recently shown to pass through the oval window into the vestibule. The successful experiment performed in guinea pigs opens the door for designing such delivery systems for treating peripheral vestibular diseases [82].

Other polymers and copolymers of interest for drug delivery include, but are not limited to, hyaluronic acid, poloxamer 407, poly (L-lactic acid) (PLLA), poly $\varepsilon$-caprolactone (PCL), polyethylene glycol (PEG), PLLA-PEG, and PLLA-PEG-PLLA [2,125].

A special class of polymeric NPs is represented by polymersomes. Moreover, called multifunctional NPs, polymersomes are amphiphilic copolymers that self-assemble into membranes of hydrophobic units around an aqueous core and a hydrophilic corona. The obtained structure resembles liposomes and has the advantage of controlling membrane thickness by the molecular weight of the copolymer's hydrophobic block to achieve stronger, 
thicker, and more stable membranes [13]. Similar to liposome-based delivery systems, polymersomes can carry hydrophilic drugs in their core and hydrophobic ones in the membrane, the biomimetic structure enabling good immune tolerance [55]. Generally, polymersomes used in inner ear delivery consist of di-block copolymers (e.g., poly(ethylene glycol)-bpoly( $\varepsilon$-caprolactone)(PEG-b-PCL) or poly(2-hydroxyethyl aspartamide) (PHEA) [55]) that, at room temperature, form quite stable systems with the encapsulated drug [125]. In this respect, various multifunctional polymersomes were studied for inner ear drug delivery targeting specific tissue or conjugated with ferromagnetic materials [13].

\subsection{Nanoparticles Incorporated in Nanocomposite Materials}

Increasing scientific interest has also been observed in developing antimicrobial nanocomposite materials incorporating some of the above-described nanoparticles. In this regard, Banerjee et al. [135] have created an iodine-doped chitosan nanoparticle composite that proved synergic activity of the three antimicrobial components against $E$. coli, while minimizing AgNPs concentration and subsequent toxicity towards mammalian cells. Ziabka et al. [88] proposed the incorporation of AgNPs into acrylonitrile butadiene styrene (ABS) polymer prosthesis to avoid infections (e.g., otitis media and chronic otitis media) in individuals requiring ossicular replacement prostheses.

Danti et al. [1] have focused their research on incorporating lithium niobate NPs into poly (vinylidene fluoride-trifluoro ethylene) fibers via electrospinning. The composite fibrous structure showed an enhanced piezoelectric response, supported human neurallike cell growth in vitro, and showed antibacterial activity against $P$. aeruginosa, being considered a promising candidate material for next-generation cochlear implants.

Another composite nanomaterial that may be of interest for drug delivery to the inner ear is represented by uniform magnetic spheres with magnetic core and mesoporous silica shell, developed by Zhao et al. [136]. The outer ceramic layer presents a high enough surface area and pore volume for encapsulating drugs, while the inner $\mathrm{Fe}_{3} \mathrm{O}_{4} / \mathrm{Fe}$ core endows this nanocomposite with magnetic properties, which are beneficial for carrying the drug to the targeted site. Namazi et al. [137] have also considered ceramic nanoparticles for creating a nanocomposite controlled-release system. The researchers fabricated an antibiotic-loaded hydroxymethylcellulose-MSNs composite hydrogel film intended for wound healing; however, its antibacterial activity against S. aureus can be useful in ear infections treatment as well.

\subsection{Nanomaterials Safety}

The studies in the field have also been focused on the safety of these nanomaterials, not only on treatment efficacy. In vitro and in vivo models were employed for assessing the effectiveness and potential side effects of several nanoparticles, focusing on parameters like cellular uptake, distribution in inner ear tissues, survival rates of treated cells, hearing threshold, and morphological changes after NPs administration.

In vitro tests are generally performed on cells from the House Ear Institute-Organ of Corti 1 (HEI-OC1) or Mouse Organ of Corti (OC-k3) cell lines, as they express many inner ear biomarkers $[1,96]$. Other models involve cells isolated from different inner ear structures of guinea pigs, rats, or mice cultured in situ [82,138-140]. Regardless of cell provenience, further experimental steps are similar. The most used method for measuring cellular metabolism as an indicator of cell viability, proliferation, and cytotoxicity is the 3-(4,5-dimethylthiazol-2-yl)-2,5-diphenyltetrazolium bromide (MTT) assay. It assumes the seeding onto a 96-well plate of cells exposed to different concentrations of NPs, followed by $24 \mathrm{~h}$ incubation. Then, the culture medium is discarded, cells are rinsed twice with phosphate-buffered saline, and MTT solution is added. After four more hours of incubation, cells are solubilized with dimethyl sulfoxide, and the plate is left on a shaker in the dark for $2 \mathrm{~h}$. In the end, the absorbance is measured at $570 \mathrm{~nm}$ and compared with control samples [96,141]. Similarly, cell viability can be determined by the CCK-8 (cell counting kit-8) assay, the main difference consisting of monitoring the absorbance at a different 
wavelength (i.e., $450 \mathrm{~nm}$ ) [142]. Another colorimetric method for investigating cytotoxicity is the 3-(4,5-dimethylthiazol2-yl)-5-(3-carboxymethoxyphenyl)-2-(4-sulfophenyl)-2Htetrazolium (MTS) assay in which cells are seeded to the 96-well plate, left $24 \mathrm{~h}$ to adhere, then treated with the NPs suspended in a complete medium at various concentrations. Cells are analyzed at 24, 48, and $72 \mathrm{~h}$ after treatment; at the end of each time point, the cells medium is changed with complete medium plus MTS-phenazine methosulfate mixture and left for three more hours to incubate. In the end, the absorbance is read at $492 \mathrm{~nm}$ and normalized to the average value of untreated samples [1].

In what concerns in vivo studies, they usually imply NPs administration to anesthetized animals by intratympanic/trans-tympanic injection, followed by different tests depending on what is desired to be measured. Experiments may be performed on alive laboratory animals if the auditory function has to be tested, or, at a certain time after treatment administration, the animals are decapitated under deep anesthesia, and the tissues of interest are carefully explanted for further analyses.

Table 1 summarizes several identified in vitro and in vivo studies investigating the potential adverse effects of nanoparticles on inner ear cells.

Table 1. Summary of studies on nanomaterials potential side effects on inner ear cells.

\begin{tabular}{|c|c|c|c|c|c|c|}
\hline $\begin{array}{c}\text { Tested } \\
\text { Nanomaterial }\end{array}$ & $\begin{array}{c}\text { Nanomaterial } \\
\text { Properties }\end{array}$ & $\begin{array}{l}\text { Type of } \\
\text { Study }\end{array}$ & Type of Cells & $\begin{array}{c}\text { Experimental } \\
\text { Design }\end{array}$ & Observations & Refs. \\
\hline LCNs & $\begin{array}{c}\text { Size: } 50 \mathrm{~nm} \\
\text { Polydispersity } \\
\text { index: }<0.2\end{array}$ & In vitro & $\begin{array}{l}\text { Cochlear cells } \\
\text { isolated from } \\
\text { newborn } \\
\text { Sprague-Dawley } \\
\text { rats }\end{array}$ & $\begin{array}{l}\text { The cells were } \\
\text { treated with LNCs } \\
\text { at concentrations } \\
\text { varying between } 0 \\
\text { and } 1.5 \mathrm{mg} / \mathrm{mL} \text { for } \\
24 \mathrm{~h} \text {. }\end{array}$ & $\begin{array}{c}\text { Survival rates of treated cells, } \\
\text { depending on concentration: } \\
\quad-1.5 \mathrm{mg} / \mathrm{mL}-37.96 \% \\
-0.15 \mathrm{mg} / \mathrm{mL}-86.41 \% \\
-0.015 \mathrm{mg} / \mathrm{mL}-80.06 \% \\
\text { Surviving cells from all treated } \\
\text { groups had fewer LNCs in their } \\
\text { cytoplasm. }\end{array}$ & {$[82,138]$} \\
\hline LCNs & $\begin{array}{l}\text { Nanoparticle size: } \\
50 \mathrm{~nm} \\
\text { Pledget size: } 8 \\
\mathrm{~mm}^{3} \\
\text { LNC } \\
\text { concentration: } \\
20.5 \mathrm{~g} / \mathrm{L}\end{array}$ & In vivo & $\begin{array}{l}\text { Interdental cells, } \\
\text { stria marginal } \\
\text { cells, outer hair } \\
\text { cells, inner hair } \\
\text { cells, } \\
\text { semi-circular } \\
\text { canal endothelial } \\
\text { cells, cochlear } \\
\text { nerve of rats }\end{array}$ & $\begin{array}{l}\text { A small piece of } \\
\text { gelatin sponge } \\
\text { pledget saturated } \\
\text { with LNCs was } \\
\text { placed on } \\
\text { the round window } \\
\text { membrane, and it } \\
\text { was there for D28 } \\
\text { for ABR study and } \\
2 \mathrm{~h} \text { for neural } \\
\text { elements studies. }\end{array}$ & $\begin{array}{l}\text { None of the animals manifested } \\
\text { middle ear infections during the } \\
\text { study. } \\
\text { No inflammation was detected } \\
\text { in the inner ear } \\
\text { LNC treatment did not induce } \\
\text { apoptosis. } \\
\text { The inner ear neural elements } \\
\text { were preserved. }\end{array}$ & [138] \\
\hline $\begin{array}{l}\text { Resveratrol- } \\
\text { loaded PLGA } \\
\text { nanoparticles }\end{array}$ & $\begin{array}{c}\text { Size: } \\
135.5 \pm 37.3 \mathrm{~nm}\end{array}$ & In vitro & $\begin{array}{l}\text { HEI-OC1 and } \\
\text { SVK-1 cell line }\end{array}$ & $\begin{array}{l}\text { The cells were } \\
\text { treated with blank } \\
\text { nanoparticle, } \\
\text { resveratrol, and } \\
\text { resveratrol-loaded } \\
\text { nanoparticles at } \\
\text { concentrations up } \\
\text { to } 1 \mathrm{mg} / \mathrm{mL} \text { for } 24 \\
\mathrm{~h} \text {. }\end{array}$ & $\begin{array}{l}\text { No cell line's viability was } \\
\text { affected by blank nanoparticles } \\
\text { in concentrations below } 0.6 \\
\text { mg } / \mathrm{mL} \\
\text { At a concentration of } 1 \mathrm{mg} / \mathrm{mL} \text {, } \\
\text { blank nanoparticles produced } \\
\text { the death of } 56 \% \text { cells from } \\
\text { HEI-OC } 1 \text { cell line } \\
\text { Resveratrol and } \\
\text { resveratrol-loaded nanoparticles } \\
\text { lead to negligible cell death } \\
\text { rates. }\end{array}$ & {$[82,143]$} \\
\hline $\begin{array}{l}\text { Polyethylenimine } \\
\text { (PEI)-plasmid } \\
\text { DNA } \\
\text { nanoparticles }\end{array}$ & $\begin{array}{l}\text { Size: } 20-100 \mathrm{~nm} \\
\text { Shape: almost } \\
\text { spherical }\end{array}$ & In vitro & $\begin{array}{c}\text { Cochlear } \\
\text { epithelium } \\
\text { isolated from } \\
\text { C57BL/6J male } \\
\text { and female mice }\end{array}$ & $\begin{array}{l}\text { The cochlear } \\
\text { explants were } \\
\text { treated with linear } \\
\text { nanoparticle } \\
\text { polyplexes loaded } \\
\text { with plasmid DNA } \\
\text { at various weight } \\
\text { ratios; the cell } \\
\text { viability was } \\
\text { assessed in a 0-48 h } \\
\text { interval after } \\
\text { transfection. }\end{array}$ & $\begin{array}{l}\text { The use of a higher linear } \\
\text { polyethylenimine-plasmid DNA } \\
\text { ratio conducted to a significant } \\
\text { time-dependent reduction in } \\
\text { hair cell viability } \\
\text { Oto-nanotoxicity of the tested } \\
\text { material started to manifest } \\
\text { immediately after the addition } \\
\text { of the poly-plex, especially outer } \\
\text { hair cells were noted to be more } \\
\text { vulnerable in the acute phase. }\end{array}$ & {$[82,139]$} \\
\hline
\end{tabular}


Table 1. Cont.

\begin{tabular}{|c|c|c|c|c|c|c|}
\hline $\begin{array}{c}\text { Tested } \\
\text { Nanomaterial }\end{array}$ & $\begin{array}{c}\text { Nanomaterial } \\
\text { Properties }\end{array}$ & $\begin{array}{l}\text { Type of } \\
\text { Study }\end{array}$ & Type of Cells & $\begin{array}{c}\text { Experimental } \\
\text { Design }\end{array}$ & Observations & Refs. \\
\hline SPIONs & $\begin{array}{c}\text { Size: } 100 \text { and } 500 \\
\mathrm{~nm}\end{array}$ & In vitro & $\begin{array}{l}\text { EC5V cells } \\
\text { derived from the } \\
\text { inner ear ampulla } \\
\text { of semicircular } \\
\text { canals. }\end{array}$ & $\begin{array}{c}\text { The cells were } \\
\text { treated with } \\
\text { SPIONs at final } \\
\text { concentrations, } \\
\text { depending on size: } \\
100 \mathrm{~nm}-3 \times 10^{10}, 3 \\
\times 10^{9}, 3 \times 10^{8} \\
\mathrm{NP} / \mathrm{mL} \\
500 \mathrm{~nm}-7 \times 10^{7}, 7 \\
\times 10^{6} \mathrm{NP} / \mathrm{mL} .\end{array}$ & $\begin{array}{c}\text { A lower number of surviving } \\
\text { cells were reported in the } 100 \\
\text { nm treated group than in the } 500 \\
\text { nm and control } \\
\text { groupsApoptotic cells were } \\
\text { more frequently observed in the } \\
100 \mathrm{~nm} \text { group than in the } 500 \\
\mathrm{~nm} \text { and control groups. }\end{array}$ & {$[82,140]$} \\
\hline SPIONs & Size: $200 \mathrm{~nm}$ & In vivo & $\begin{array}{l}\text { Inner ear cells of } \\
\text { albino male } \\
\text { guinea pigs }\end{array}$ & $\begin{array}{l}\text { In each animal, on } \\
\text { one ear, a } 0.4 \mathrm{~mm} \\
\text { scala tympani } \\
\text { cochleostomy, } 1.5 \\
\text { mm under the } \\
\text { round window } \\
\text { ridge was } \\
\text { performed through } \\
\text { a posterior } \\
\text { approach and } \\
\text { bullostomy and } 1 \\
\mu \mathrm{L} \text { of saline serum } \\
\text { was injected. In the } \\
\text { other ear, a bolus of } \\
1 \mu \mathrm{L} \text { of } \\
\text { nanoparticles was } \\
\text { performed using } \\
\text { the same method. }\end{array}$ & $\begin{array}{l}\text { At day } 7 \text {, hearing threshold shift } \\
\text { showed no difference between } \\
\text { saline-treated ears and } \\
\text { nanoparticles treated ears. }\end{array}$ & {$[140]$} \\
\hline AuNPs & $\begin{array}{c}\text { Size: } 50 \mathrm{~nm} \\
\text { Shape: spherical }\end{array}$ & In vitro & HEI-OC1 cell line & $\begin{array}{c}\text { The cells were } \\
\text { treated with } \\
\text { nanoparticles at } \\
0-100 \mu \mathrm{M} \text { for up to } \\
6 \text { days }\end{array}$ & $\begin{array}{c}\text { There were not reported any } \\
\text { significant changes in cell } \\
\text { viability. }\end{array}$ & {$[82,96]$} \\
\hline AuNPs & $\begin{array}{c}\text { Size: } 50 \mathrm{~nm} \\
\text { Shape: } \text { spherical }\end{array}$ & In vivo & $\begin{array}{l}\text { Mouse cochlear } \\
\text { cells }\end{array}$ & $\begin{array}{l}\text { Gold nanoparticles } \\
\text { were applied } \\
\text { in vivo to mouse } \\
\text { cochleae }\end{array}$ & $\begin{array}{l}\text { The injected nanoparticles fully } \\
\text { diffused throughout the inner } \\
\text { ear and were successfully } \\
\text { localized within the cells. } \\
\text { The presence of nanoparticles } \\
\text { had no observable effect on the } \\
\text { morphology of the hair cells. } \\
\text { Gold nanoparticles do not } \\
\text { enhance X-ray attenuation in a } \\
\text { significant manner. Hence they } \\
\text { are not considered suitable } \\
\text { computed tomography imaging } \\
\text { contrast agents for the inner ear. }\end{array}$ & [96] \\
\hline $\begin{array}{l}\text { Methoxy poly } \\
\text { (ethylene } \\
\text { glycol)-polylactic } \\
\text { acid } \\
\text { nanoparticles } \\
\text { loaded with } \\
\text { dexamethasone }\end{array}$ & $\begin{array}{c}\text { Size: } 130 \mathrm{~nm} \\
\text { Shape: spherical }\end{array}$ & In vivo & $\begin{array}{l}\text { Inner ear cells of } \\
\text { male guinea pigs }\end{array}$ & $\begin{array}{l}\text { The treatment was } \\
\text { administered } \\
\text { intraperitoneally at } \\
\text { a dose of } 10 \mathrm{mg} / \mathrm{kg} \\
\text { and at a } \\
\text { concentration of } 10 \\
\mathrm{mg} / \mathrm{mL}, 1 \mathrm{~h} \text { before } \\
\text { cisplatin injection. } \\
\text { Three days after } \\
\text { treatment, the } \\
\text { animals were } \\
\text { euthanized, and } \\
\text { their tissues were } \\
\text { prepared for the } \\
\text { examination. }\end{array}$ & $\begin{array}{l}\text { The auditory brainstem } \\
\text { response threshold was not } \\
\text { significantly changed, indicating } \\
\text { nanoparticles' nontoxicity. } \\
\text { A single injection of } \\
\text { nanoparticles was reported to } \\
\text { provide significant functional } \\
\text { and histological protection of } \\
\text { the cochlea from the cisplatin, } \\
\text { which was similar to the effect } \\
\text { of repeated injection of the free } \\
\text { drug for } 3 \text { days. }\end{array}$ & {$[144]$} \\
\hline
\end{tabular}


Table 1. Cont.

\begin{tabular}{|c|c|c|c|c|c|c|}
\hline $\begin{array}{c}\text { Tested } \\
\text { Nanomaterial }\end{array}$ & $\begin{array}{c}\text { Nanomaterial } \\
\text { Properties }\end{array}$ & $\begin{array}{l}\text { Type of } \\
\text { Study }\end{array}$ & Type of Cells & $\begin{array}{c}\text { Experimental } \\
\text { Design }\end{array}$ & Observations & Refs. \\
\hline $\begin{array}{c}\text { Unmodified } \\
\text { PLGA- } \\
\text { nanoparticles, } \\
\text { surface modified } \\
\text { with poloxamer } \\
\text { 407, chitosan, or } \\
\text { methoxy } \\
\text { poly(ethylene } \\
\text { glycol) }\end{array}$ & $\begin{array}{c}\text { Size: } 100-200 \mathrm{~nm} \\
\text { Relatively } \\
\text { uniform size } \\
\text { distribution }\end{array}$ & In vitro & HEI-OC1 cell line & $\begin{array}{c}\text { The cells were } \\
\text { treated with } \\
\text { nanoparticles at } \\
\text { concentrations } \\
\text { varying between } 0 \\
\text { and } 80 \mathrm{mg} / \mathrm{mL} \text { for } \\
24 \mathrm{~h}\end{array}$ & $\begin{array}{c}\text { IC }_{50} \text { values: } \\
\text { (1) unmodified NPs-71.30 } \pm \\
4.16 \mathrm{mg} / \mathrm{mL} \\
\text { (2) P407-modified NPs-60.53 } \pm \\
0.55 \mathrm{mg} / \mathrm{mL} \\
\text { (3) Chitosan-modified } \\
\text { NPs-65.39 } \pm 0.47 \mathrm{mg} / \mathrm{mL} \\
\text { (4) } \mathrm{mPEG-modified} \mathrm{NPs-81.70} \\
\pm 1.04 \mathrm{mg} / \mathrm{mL} \\
\text { Uptake efficiencies: } \\
\text { (1) unmodified NPs-79.7\% } \\
\text { (2) P407-modified NPs-91.4\% } \\
\text { (3) Chitosan-modified } \\
\text { NPs-58.3\% } \\
\text { (4) mPEG-modified NPs-48.1\% }\end{array}$ & {$[82,142]$} \\
\hline $\begin{array}{c}\text { Unmodified } \\
\text { PLGA- } \\
\text { nanoparticles, } \\
\text { surface modified } \\
\text { with poloxamer } \\
\text { 407, chitosan, or } \\
\text { methoxypoly } \\
\text { (ethylene glycol) }\end{array}$ & $\begin{array}{c}\text { Size: } 100-200 \mathrm{~nm} \\
\text { Relatively } \\
\text { uniform size } \\
\text { distribution }\end{array}$ & In vivo & $\begin{array}{l}\text { Inner ear cells of } \\
\text { albino guinea } \\
\text { pigs }\end{array}$ & $\begin{array}{l}\text { The four types of } \\
\text { nanoparticles were } \\
\text { injected at a } \\
\text { concentration of } 25 \\
\mathrm{mg} / \mathrm{mL} \text { into the } \\
\text { unilateral tympanic } \\
\text { cavity of the guinea } \\
\text { pigs. They were } \\
\text { examined } 24 \mathrm{~h} \text { after } \\
\text { administration }\end{array}$ & $\begin{array}{l}\text { No inflammation was detected } \\
\text { in the inner ear } \\
\text { Several tissues, such as stria } \\
\text { vascularis, spiral ligament, } \\
\text { organ of Corti, and spiral } \\
\text { ganglion cells, barely underwent } \\
\text { morphological alterations after } \\
\text { nanoparticles administration } \\
\text { The hydrophilic coating of } \\
\text { PLGA nanoparticles played an } \\
\text { important role in inner ear } \\
\text { transport, particularly the P407 } \\
\text { modification } \\
\text { The surface-modified } \\
\text { nanoparticles were considerably } \\
\text { localized in the spiral ligament, } \\
\text { stria vascularis, organ of Corti, } \\
\text { and spiral ganglion cells, while } \\
\text { the unmodified particles were } \\
\text { distributed marginally }\end{array}$ & [142] \\
\hline $\begin{array}{c}\text { Chitosan } \\
\text { nanoparticles }\end{array}$ & $\begin{array}{c}\text { Average size: } \\
152.7 \mathrm{~nm} \\
\text { Polydispersity } \\
\text { index: } 0.135 \\
\text { Shape: spherical }\end{array}$ & In vitro & HEI-OC1 cell line & $\begin{array}{c}\text { The cells were } \\
\text { treated with } \\
\text { nanoparticles at } \\
\text { concentrations } \\
\text { varying between } 0 \\
\text { and } 2.5 \mathrm{mg} / \mathrm{mL} \text { for } \\
24 \mathrm{~h}\end{array}$ & $\begin{array}{l}\text { There was not reported any } \\
\text { significant change in cell } \\
\text { viability } \\
\text { Nanoparticles were internalized } \\
\text { in cells with an } 89.1 \% \text { uptake } \\
\text { efficiency }\end{array}$ & {$[82,130]$} \\
\hline $\begin{array}{c}\text { Chitosan } \\
\text { nanoparticles }\end{array}$ & $\begin{array}{c}\text { Average size: } \\
152.7 \mathrm{~nm} \\
\text { Polydispersity } \\
\text { index: } 0.135 \\
\text { Shape: spherical }\end{array}$ & In vivo & $\begin{array}{l}\text { Inner ear cells of } \\
\text { guinea pigs }\end{array}$ & $\begin{array}{l}\text { The nanoparticles } \\
\text { were injected at a } \\
\text { concentration of } 2.5 \\
\mathrm{mg} / \mathrm{mL} \text { into the } \\
\text { unilateral tympanic } \\
\text { cavity of the guinea } \\
\text { pigs. The animals } \\
\text { were decapitated } 1 \\
\mathrm{~h} \text { after the } \\
\text { treatment and } \\
\text { examined after } 24 \mathrm{~h}\end{array}$ & $\begin{array}{l}\text { The number of surviving hair } \\
\text { cells hardly decreased, } \\
\text { indicating the safety of the } \\
\text { tested nanoparticles. } \\
\text { The chitosan nanoparticles were } \\
\text { successfully delivered into the } \\
\text { vestibule, accumulating } \\
\text { significantly more in the } \\
\text { vestibular system than in the } \\
\text { cochlear tissues } \\
\text { The nanoparticle uptake in } \\
\text { saccular supporting cells was } \\
\text { much higher compared to } \\
\text { cochlear hair cells of middle and } \\
\text { apical turns }\end{array}$ & {$[130]$} \\
\hline
\end{tabular}


Table 1. Cont.

\begin{tabular}{|c|c|c|c|c|c|c|}
\hline $\begin{array}{c}\text { Tested } \\
\text { Nanomaterial }\end{array}$ & $\begin{array}{c}\text { Nanomaterial } \\
\text { Properties }\end{array}$ & $\begin{array}{l}\text { Type of } \\
\text { Study }\end{array}$ & Type of Cells & $\begin{array}{l}\text { Experimental } \\
\text { Design }\end{array}$ & Observations & Refs. \\
\hline $\begin{array}{c}\text { Lipid } \\
\text { nanoparticles- } \\
\text { encapsulated } \\
\text { brain-derived } \\
\text { neurotrophic } \\
\text { factor (BDNF) } \\
\text { mRNA }\end{array}$ & $\begin{array}{c}\text { Lipid } \\
\text { composition: } \\
\text { SS-cleavable and } \\
\text { pH-activated } \\
\text { lipid-like mate- } \\
\text { rial:dioleolyphosphatic } \\
\text { ethanolamine } \\
\text { (DOPE):cholesterol= } \\
\text { 3:3:4 }\end{array}$ & $\begin{array}{l}\text { In vivo } \\
\text { idyl }\end{array}$ & $\begin{array}{c}\text { Inner ear cells of } \\
\text { Hartley guinea } \\
\text { pigs }\end{array}$ & $\begin{array}{l}\text { The animals were } \\
\text { intramuscularly } \\
\text { injected with } \\
\text { gentamicin, } \\
\text { promptly followed } \\
\text { by intravenous } \\
\text { injection of } \\
\text { ethacrynic acid. On } \\
\text { day 1, for early } \\
\text { therapy, or day } 14, \\
\text { for late therapy, } 5 \mu l \\
\text { of lipid } \\
\text { nanoparticles } \\
\text { loaded with } 0.1 \\
\text { mg/mL BDNF } \\
\text {-enhanced green } \\
\text { fluorescent protein } \\
\text { mRNA was } \\
\text { administered }\end{array}$ & $\begin{array}{c}\text { On day } 1 \text { after gentamicin } \\
\text { exposure, the auditory } \\
\text { thresholds of the group } \\
\text { administered with nanoparticles } \\
\text { significantly improved } \\
\text { compared to the sham control } \\
\text { group. } \\
\text { The auditory thresholds did not } \\
\text { differ significantly between the } \\
\text { sham control group and animals } \\
\text { administered with nanoparticles } \\
14 \text { days after gentamicin } \\
\text { exposure. } \\
\text { The outer hair cells in the } \\
\text { cochlea of the group treated } 1 \\
\text { day after gentamicin exposure } \\
\text { were significantly decreased } \\
\text { compared with those in the } \\
\text { control group, while inner hair } \\
\text { cells counts had no significant } \\
\text { differences in all turns among all } \\
\text { groups. }\end{array}$ & [145] \\
\hline $\begin{array}{l}\text { Lithium niobate } \\
\text { NPs }\end{array}$ & $\begin{array}{l}\text { Size range: } \\
\text { 200-600 nm } \\
\text { Average size: } \\
392.25 \mathrm{~nm} \\
\text { Polydispersity } \\
\text { index: } 0.517\end{array}$ & In vitro & OC-k3 cell line & $\begin{array}{l}\text { (1) Cytotoxicity of } \\
\text { nanoparticles was } \\
\text { investigated using } \\
\text { the MTS assay. The } \\
\text { OC-k3 cells were } \\
\text { seeded in 96-well } \\
\text { plates at the } \\
\text { concentration of } \\
7000 \text { cells / well in } \\
100 \text { } \mu \text { L of medium } \\
\text { and left to adhere } \\
\text { for } 24 \text { h at ambient } \\
\text { temperature after } \\
\text { which were treated } \\
\text { with the compound } \\
\text { resuspended in a } \\
\text { complete medium } \\
\text { at three different } \\
\text { concentrations: } 0.85, \\
15, \text { and } 74 \text { ng/mL. } \\
\text { Vitality was } \\
\text { analyzed } 24,48, \text { and } \\
72 \mathrm{~h} \text { after treatment. } \\
\text { (2) Similarly, a } \\
\text { morphological test } \\
\text { was performed by } \\
\text { seeding and } \\
\text { culturing the cells } \\
\text { on a round glass } \\
\text { slide. }\end{array}$ & $\begin{array}{l}\text { The tested nanoparticles } \\
\text { induced a significant increase in } \\
\text { cell viability after } 72 \mathrm{~h} \text { of } \\
\text { incubation at the concentrations } \\
\text { of } 0.0085 \text { and } 0.015 \mu \mathrm{g} / \mathrm{mL} \text {. } \\
\text { The morphological test proved a } \\
\text { good state of cellular health. No } \\
\text { cell morphology alterations } \\
\text { were noticed at any of the tested } \\
\text { doses and time points. }\end{array}$ & {$[1]$} \\
\hline
\end{tabular}

Zhang et al. [138] demonstrated that an increase in LCNs concentration leads to a decrease in the in vitro viability of the inner ear cochlea cells. Nonetheless, LCNs with sizes below $100 \mathrm{~nm}$ are biodegradable, and their in vivo administration does not produce any infection, inflammation, hearing impairment, cell death, or morphological changes in the inner ear. Zhou et al. [139] reported a time-dependent decrease in cell viability of mice cultured cochlear epithelium treated with linear PEI-plasmid DNA-NPs, and several concerns are to be solved before in vivo testing (e.g., PEI limited biodegradability, high cationic charge density, production of intracellular reactive oxygen species). An ototoxicity-size dependency was observed in vitro by Nguyen et al. [140]. However, in vivo administration of SPIONs of $200 \mathrm{~nm}$ has shown no difference in hearing threshold compared to 
saline-treated ears, rendering these NPs as promising vectors for controlled delivery to cochlear targeted cells. Musazzi et al. [143] have registered increasing cell death rates with increasing doses of resveratrol-loaded PLGA NPs. Particularly, cell viability decreased in HEI-OC1 cells exposed to high concentrations of the tested NPs, while SVK-1 cells proved to be more resistant to NPs exposure; nonetheless, future experiments are needed for deeply investigating cellular uptake mechanisms and intracellular release of the loaded drug. PLGA NPs were also evaluated by Wen et al. [142]. The researchers tested different surface-modified polymer NPs, concluding that biocompatible PLGA-based nanocarriers, if functionalized with hydrophilic molecules, have a greater capacity to penetrate outer hair cells, thus allowing a more efficient hearing loss therapy. No significant toxicity, no observable changes in cell viability, cell morphology, or auditory brainstem response were reported for AuNPs [96], chitosan NPs [130], methoxy poly (ethylene glycol)-polylactic acid nanoparticles loaded with dexamethasone [144], lipid nanoparticles-encapsulated brain-derived neurotrophic factor mRNA [145], and lithium niobate NPs [1].

In conclusion, a general observation that can be drawn from these studies is that ototoxicity is highly dependent on nanoparticle size and concentration, while NPs functionalization dictates distribution into targeted tissues and uptake efficiency. Hence, these factors must be thoroughly considered when designing nanoparticles-based treatments for the inner ear.

\section{Conclusions and Future Perspectives}

To summarize, the inner ear is sensitive to various bacterial, viral, and fungal infections, which may produce permanent sensorineural hearing loss. If left untreated, such infections can progress to neighboring tissues and cause intracranial infectious complications. Therefore, prompt treatment is required. The necessary medication can be administered in several ways, such as systemic delivery, intratympanic injection, and direct inner ear delivery. However, each method has limitations in overcoming the inner ear barriers.

A promising solution for an efficient and targeted treatment of inner ear infections comes from the field of nanotechnology. Different types of nanoparticles were designed and tested either directly against pathogens or as carriers of various drugs. Several inorganic, lipid and polymeric-based nanoplatforms were shown to improve drugs' local application, enhancing antimicrobial performance while diminishing the systemic side effects. Studies were also performed on the safety of nanoparticles' use for inner ear delivery, demonstrating that most of these materials are harmless for healthy tissues.

However, there is a lack of information concerning nanomaterials ear toxicity in human beings, possible adverse effects in organ systems which are not generally considered primary ototoxic targets, and long-term impact on ear health. Hence, future studies must also consider elucidating these aspects of nanoparticle-mediated treatments.

A promising future perspective for treating inner ear infections would be the development of biocompatible multifunctional nanoparticles capable of targeting specific cells, deliver drugs in a controlled manner, and biodegrade into harmless entities that can be easily eliminated from the organism. Alternatively, multifunctionality should be sought by designing synergic composite nanomaterials.

To conclude, current research results indicate the great potential of nanoparticles in treating various inner ear diseases. It can be expected that certain nanomaterials or nano-enabled products would soon be available as therapeutic options. Nonetheless, more in vivo studies must be carried out before moving to clinical applications.

Author Contributions: D.C.G., A.-G.N., A.C.B. and A.M.G. participated in the review, writing, and revision. All authors have read and agreed to the published version of the manuscript.

Funding: This work was supported by a grant from the Romanian National Authority for Scientific Research and Innovation, UEFISCDI, project number 45PCCDI/2018-Nanostructuri bioactive pentru strategii terapeutice inovatoare. 
Conflicts of Interest: The authors declare no conflict of interest.

\section{References}

1. Danti, S.; Azimi, B.; Candito, M.; Fusco, A.; Bafqi, M.S.S.; Ricci, C.; Milazzo, M.; Cristallini, C.; Latifi, M.; Donnarumma, G.; et al. Lithium niobate nanoparticles as biofunctional interface material for inner ear devices. Biointerphases 2020, 15, 031004. [CrossRef]

2. Nguyen, K.; Kempfle, J.S.; Jung, D.H.; McKenna, C.E. Recent advances in therapeutics and drug delivery for the treatment of inner ear diseases: A patent review (2011-2015). Expert Opin. Ther. Patents 2016, 27, 191-202. [CrossRef]

3. Ren, Y.; Landegger, L.D.; Stankovic, K.M. Gene Therapy for Human Sensorineural Hearing Loss. Front. Cell. Neurosci. 2019, 13, 323. [CrossRef] [PubMed]

4. Wood, J.W.; Shaffer, A.D.; Kitsko, D.; Chi, D.H. Sudden Sensorineural Hearing Loss in Children-Management and Outcomes: A Meta-analysis. Laryngoscope 2021, 131, 425-434. [CrossRef]

5. Lang, B.; Hintze, J.; Conlon, B. Coronavirus disease 2019 and sudden sensorineural hearing loss. J. Laryngol. Otol. 2020, 134, 1026-1028. [CrossRef] [PubMed]

6. Vinhaes, E.S.; Santos, L.A.; Dias, L.; Andrade, N.A.; Bezerra, V.H.; De Carvalho, A.T.; De Moraes, L.; Henriques, D.F.; Azar, S.R.; Vasilakis, N.; et al. Transient Hearing Loss in Adults Associated with Zika Virus Infection. Clin. Infect. Dis. 2016, 6, 675-677. [CrossRef]

7. Korver, A.M.H.; Smith, R.J.H.; Van Camp, G.; Schleiss, M.R.; Bitner-Glindzicz, M.A.K.; Lustig, L.R.; Usami, S.-I.; Boudewyns, A.N. Congenital hearing loss. Nat. Rev. Dis. Prim. 2017, 3, 1-17. [CrossRef] [PubMed]

8. Muri, L.; Le, N.D.; Zemp, J.; Grandgirard, D.; Leib, S.L. Metformin mediates neuroprotection and attenuates hearing loss in experimental pneumococcal meningitis. J. Neuroinflamm. 2019, 16, 1-14. [CrossRef]

9. Zhang, Z.; Li, X.; Zhang, W.; Kohane, D.S. Drug Delivery across Barriers to the Middle and Inner Ear. Adv. Funct. Mater. 2020. [CrossRef]

10. McCall, A.A.; Swan, E.E.L.; Borenstein, J.T.; Sewell, W.F.; Kujawa, S.G.; McKenna, M.J. Drug Delivery for Treatment of Inner Ear Disease: Current State of Knowledge. Ear Hear. 2010, 31, 156-165. [CrossRef]

11. Mäder, K.; Lehner, E.; Liebau, A.; Plontke, S.K. Controlled drug release to the inner ear: Concepts, materials, mechanisms, and performance. Hear. Res. 2018, 368, 49-66. [CrossRef]

12. Mittal, R.; Pena, S.A.; Zhu, A.; Eshraghi, N.; Fesharaki, A.; Horesh, E.J.; Mittal, J.; Eshraghi, A.A. Nanoparticle-based drug delivery in the inner ear: Current challenges, limitations and opportunities. Artif. Cells Nanomed. Biotechnol. 2019, 47, 1312-1320. [CrossRef] [PubMed]

13. Valente, F.; Astolfi, L.; Simoni, E.; Danti, S.; Franceschini, V.; Chicca, M.; Martini, A. Nanoparticle drug delivery systems for inner ear therapy: An overview. J. Drug Deliv. Sci. Technol. 2017, 39, 28-35. [CrossRef]

14. An, X.; Zha, D. Development of nanoparticle drug-delivery systems for the inner ear. Nanomedicine 2020, 15, 1981-1993. [CrossRef]

15. Dewyer, N.A.; Kiringoda, R.; McKenna, M.J. Inner Ear Infections (Labyrinthitis). In Infections of the Ears, Nose, Throat, and Sinuses; Springer Science and Business Media LLC: Berlin/Heidelberg, Germany, 2018; pp. 79-88.

16. Prince, A.D.P.; Stucken, E.Z. Sudden Sensorineural Hearing Loss: A Diagnostic and Therapeutic Emergency. J. Am. Board Fam. Med. 2021, 34, 216-223. [CrossRef] [PubMed]

17. Bontempo, L.J.; Shoenberger, J. Ear, Nose, and Throat Emergencies, An Issue of Emergency Medicine Clinics of North America, E-Book; Elsevier Health Sciences: Amsterdam, The Netherlands, 2018; Volume 37.

18. Barkwill, D.; Arora, R. Labyrinthitis; StatPearls: Treasure Island, FL, USA, 2020.

19. Yorgancılar, E.; Yıldırım, M.; Gun, R.; Bakır, S.; Tekın, R.; Gocmez, C.; Merıc, F.; Topcu, I. Complications of chronic suppurative otitis media: A retrospective review. Eur. Arch. Oto-Rhino-Laryngol. 2012, 270, 69-76. [CrossRef] [PubMed]

20. Smith, T.; Rider, J.; Cen, S.; Borger, J. Vestibular Neuronitis; StatPearls: Treasure Island, FL, USA, 2020.

21. Lee, J.Y.; Kim, M.B. Importance of Video Head Impulse Test Parameters for Recovery of Symptoms in Acute Vestibular Neuritis. Otol. Neurotol. 2020, 41, 964-971. [CrossRef]

22. Kim, J.S. When the Room Is Spinning: Experience of Vestibular Neuritis by a Neurotologist. Front. Neurol. 2020, 11, 157. [CrossRef]

23. Innovative Genomics Institute. Glossary. Available online: https://innovativegenomics.org/glossary/ (accessed on 2 April 2021).

24. BD Editors. Septate vs. Non-Septate Hyphae. Available online: https://biologydictionary.net/septate-vs-non-septate-hyphae/ (accessed on 2 April 2021).

25. Khan, A.; Jain, S.K. Fungal Otomycosis in Swimmers. Int. J. Life Sci. Bioeng. 2019, 6, 1-8.

26. Mustafa, M. Audiological profile of asymptomatic Covid-19 PCR-positive cases. Am. J. Otolaryngol. 2020, 41, 102483. [CrossRef]

27. Gabrielli, L.; Bonasoni, M.P.; Santini, D.; Piccirilli, G.; Chiereghin, A.; Guerra, B.; Landini, M.P.; Capretti, M.G.; Lanari, M.; Lazzarotto, T. Human fetal inner ear involvement in congenital cytomegalovirus infection. Acta Neuropathol. Commun. 2013, 1, 63. [CrossRef]

28. Sao, T.; Navya, A. Profiling of Audiological Characteristics in Infants with Congenital Rubella Syndrome. J. Otolaryngol. ENT Res. $2017,7,226$

29. Orman, G.; Kukreja, M.; Vallejo, J.; Desai, N.; Huisman, T.; Kralik, S. Accuracy of MR Imaging for Detection of Sensorineural Hearing Loss in Infants with Bacterial Meningitis. Am. J. Neuroradiol. 2020, 41, 1081-1086. [CrossRef] [PubMed] 
30. Jung, J.; Yoo, J.E.; Choe, Y.H.; Park, S.C.; Lee, H.J.; Lee, H.J.; Noh, B.; Kim, S.H.; Kang, G.-Y.; Lee, K.-M.; et al. Cleaved Cochlin Sequesters Pseudomonas aeruginosa and Activates Innate Immunity in the Inner Ear. Cell Host Microbe 2019, 25, 513-525.e6. [CrossRef] [PubMed]

31. Davis, L.E.; Johnsson, L.G. Viral infections of the Inner Ear. Am. J. Otolaryngol. 1983, 4, 347-362. [CrossRef]

32. Leal, M.D.C.; Ramos, D.S.; Neto, S.S.C. Hearing Loss From Congenital Zika Virus Infection. Top. Magn. Reson. Imaging 2019, 28, 19-22. [CrossRef]

33. Palma, S.; Roversi, M.F.; Bettini, M.; Mazzoni, S.; Pietrosemoli, P.; Lucaccioni, L.; Berardi, A.; Genovese, E. Hearing loss in children with congenital cytomegalovirus infection: An 11-year retrospective study based on laboratory database of a tertiary paediatric hospital. Acta Otorhinolaryngol. Italy 2019, 39, 40-45. [CrossRef]

34. Pinninti, S.; Christy, J.; Almutairi, A.; Cochrane, G.; Fowler, K.B.; Boppana, S. Vestibular, Gaze, and Balance Disorders in Asymptomatic Congenital Cytomegalovirus Infection. Pediatrics 2021, 147, e20193945. [CrossRef]

35. Riga, M.; Korres, G.; Chouridis, P.; Naxakis, S.; Danielides, V. Congenital cytomegalovirus infection inducing non-congenital sensorineural hearing loss during childhood: A systematic review. Int. J. Pediatr. Otorhinolaryngol. 2018, 115, 156-164. [CrossRef]

36. Martinez-Gomez, E.; Perez-Carpena, P.; Flook, M.; Lopez-Escamez, J. A Systematic Review on the Association of Acquired Human Cytomegalovirus Infection with Hearing Loss. J. Clin. Med. 2020, 9, 4011. [CrossRef]

37. Leruez-Ville, M.; Foulon, I.; Pass, R.; Ville, Y. Cytomegalovirus infection during pregnancy: State of the science. Am. J. Obstet. Gynecol. 2020, 223, 330-349. [CrossRef] [PubMed]

38. Mawson, A.R.; Croft, A.M. Rubella Virus Infection, the Congenital Rubella Syndrome, and the Link to Autism. Int. J. Environ. Res. Public Health 2019, 16, 3543. [CrossRef]

39. Caroça, C.; Vicente, V.; Campelo, P.; Chasqueira, M.; Caria, H.; Silva, S.N.; Paixão, P.; Paço, J. Rubella in Sub-Saharan Africa and sensorineural hearing loss: A case control study. BMC Public Health 2017, 17, 146. [CrossRef] [PubMed]

40. Mittal, R.; Liu, X.Z.; Fifer, R.C. A Possible Association Between Hearing Loss and Zika Virus Infections. JAMA Otolaryngol. Neck Surg. 2017, 144, 3-4. [CrossRef] [PubMed]

41. Yee, K.T.; Neupane, B.; Bai, F.; Vetter, D.E. Zika virus infection causes widespread damage to the inner ear. Hear. Res. 2020, 395, 108000. [CrossRef] [PubMed]

42. Swain, S.K.; Pani, S.R. Incidence of Hearing Loss in COVID-19 Patients: A COVID Hospital-based Study in the Eastern Part of India. Int. J. Curr. Res. Rev. 2021, 13, 103-107. [CrossRef]

43. Ribeiro, G.E.; Silva, D.P.C.d. Audiological implications of COVID-19: An integrative literature review. Revista CEFAC 2021, 23. [CrossRef]

44. Jatto, M.E.; Adeyemo, A.A.; Ogunkeyede, S.A.; Lagunju, I.A.; Nwaorgu, O.G. Pediatric Hearing Thresholds Post-bacterial Meningitis. Front. Surg. 2020, 7, 36. [CrossRef]

45. Mohammed, R.Q.; Abdullah, P.B. Infection with Acute Otitis Media Caused by Pseudomonas aeruginosa (MDR) and Staphylococcus aureus (MRSA). Biochem. Cell. Arch. 2020, 20, 905-908.

46. Calabrese, E.J.; Dhawan, G. Historical use of X-rays. Hum. Exp. Toxicol. 2013, 33, 542-553. [CrossRef]

47. Juyal, D.; Sharma, M.; Negi, V.; Prakash, R.; Sharma, N. Pseudomonas aeruginosa and its sensitivity spectrum in chronic suppurative otitis media: A study from Garhwal hills of Uttarakhand State, India. Indian J. Otol. 2017, 23, 180. [CrossRef]

48. Meyerhoff, W.L.; Paparella, M.M.; Oda, M.; Shea, D. Mycotic Infections of the Inner Ear. Laryngoscope 1979, 89, 1725-1734. [CrossRef] [PubMed]

49. Falser, N. Fungal Infection of the Ear. Dermatology 1984, 169, 135-140. [CrossRef]

50. Mofatteh, M.R.; Yazdi, Z.N.; Yousefi, M.; Namaei, M.H. Comparison of the recovery rate of otomycosis using betadine and clotrimazole topical treatment. Braz. J. Otorhinolaryngol. 2018, 84, 404-409. [CrossRef]

51. Jaudoin, C.; Agnely, F.; Nguyen, Y.; Ferrary, E.; Bochot, A. Nanocarriers for drug delivery to the inner ear: Physicochemical key parameters, biodistribution, safety and efficacy. Int. J. Pharm. 2021, 592, 120038. [CrossRef]

52. Perin, P.; Marino, F.; Varela-Nieto, I.; Szczepek, A.J. Editorial: Neuroimmunology of the Inner Ear. Front. Neurol. 2021, 12, 635359. [CrossRef]

53. Juhn, S.K. Barrier Systems in the Inner Ear. Acta Oto-Laryngol. 1988, 105, 79-83. [CrossRef]

54. Nyberg, S.; Abbott, N.J.; Shi, X.; Steyger, P.S.; Dabdoub, A. Delivery of therapeutics to the inner ear: The challenge of the blood-labyrinth barrier. Sci. Transl. Med. 2019, 11, eaao0935. [CrossRef]

55. El Kechai, N.; Agnely, F.; Mamelle, E.; Nguyen, Y.; Ferrary, E.; Bochot, A. Recent advances in local drug delivery to the inner ear. Int. J. Pharm. 2015, 494, 83-101. [CrossRef]

56. Szeto, B.; Chiang, H.; Bs, C.V.; Yu, M.; Kysar, J.W.; Lalwani, A.K. Inner ear delivery: Challenges and opportunities. Laryngoscope 2020, 5, 122-131. [CrossRef]

57. Zou, J.; Pyykkö, I.; Hyttinen, J. Inner ear barriers to nanomedicine-augmented drug delivery and imaging. J. Otol. 2016, 11, 165-177. [CrossRef]

58. Hao, J.; Li, S.K. Inner ear drug delivery: Recent advances, challenges, and perspective. Eur. J. Pharm. Sci. 2019, 126, 82-92. [CrossRef] [PubMed]

59. Guigou, C.; Lalande, A.; Millot, N.; Belharet, K.; Grayeli, A.B. Use of Super Paramagnetic Iron Oxide Nanoparticles as Drug Carriers in Brain and Ear: State of the Art and Challenges. Brain Sci. 2021, 11, 358. [CrossRef] [PubMed] 
60. Yang, K.J.; Son, J.; Jung, S.Y.; Yi, G.; Yoo, J.; Kim, D.-K.; Koo, H. Optimized phospholipid-based nanoparticles for inner ear drug delivery and therapy. Biomaterials 2018, 171, 133-143. [CrossRef] [PubMed]

61. Liu, H.; Hao, J.; Li, K.S. Current strategies for drug delivery to the inner ear. Acta Pharm. Sin. B 2013, 3, 86-96. [CrossRef]

62. Kim, D.K. Nanomedicine for Inner Ear Diseases: A Review of Recent In Vivo Studies. BioMed Res. Int. 2017, 2017, 1-6. [CrossRef] [PubMed]

63. Patel, J.; Szczupak, M.; Rajguru, S.; Balaban, C.; Hoffer, M.E. Inner Ear Therapeutics: An Overview of Middle Ear Delivery. Front. Cell. Neurosci. 2019, 13, 261. [CrossRef]

64. Manrique-Huarte, R.; de Linera-Alperi, M.A.; Parilli, D.; Rodriguez, J.; Borro, D.; Dueck, W.; Smyth, D.; Salt, A.; Manrique, M. Inner ear drug delivery through a cochlear implant: Pharmacokinetics in a Macaque experimental model. Hear. Res. 2021, 404, 108228. [CrossRef]

65. Plontke, S.K.; Götze, G.; Rahne, T.; Liebau, A. Intracochlear drug delivery in combination with cochlear implants: Current aspects. HNO 2016, 65, 19-28. [CrossRef]

66. Prenzler, N.K.; Salcher, R.; Timm, M.; Gaertner, L.; Lenarz, T.; Warnecke, A. Intracochlear administration of steroids with a catheter during human cochlear implantation: A safety and feasibility study. Drug Deliv. Transl. Res. 2018, 8, 1191-1199. [CrossRef]

67. Lehner, E.; Menzel, M.; Gündel, D.; Plontke, S.K.; Mäder, K.; Klehm, J.; Kielstein, H.; Liebau, A. Microimaging of a novel intracochlear drug delivery device in combination with cochlear implants in the human inner ear. Drug Deliv. Transl. Res. 2021. [CrossRef]

68. Ito, J.; Endo, T.; Nakagawa, T.; Kita, T.; Kim, T.-S.; Iguchi, F. A New Method for Drug Application to the Inner Ear. ORL 2005, 67, 272-275. [CrossRef]

69. Shinohara, T.; Bredberg, G.; Ulfendahl, M.; Pyykkö, I.; Olivius, N.P.; Kaksonen, R.; Lindstrom, B.; Altschuler, R.; Miller, J.M. Neurotrophic factor intervention restores auditory function in deafened animals. Proc. Natl. Acad. Sci. USA 2002, 99, 1657-1660. [CrossRef] [PubMed]

70. Ylikoski, J.; Pirvola, U.; Virkkala, J.; Suvanto, P.; Liang, X.Q.; Magal, E.; Altschuler, R.; Miller, J.; Saarma, M. Guinea pig auditory neurons are protected by glial cell line-derived growth factor from degeneration after noise trauma. Hear. Res. 1998, 124, 17-26. [CrossRef]

71. Brown, J.; Miller, J.M.; Altschuler, R.A.; Nuttall, A.L. Osmotic pump implant for chronic infusion of drugs into the inner ear. Hear. Res. 1993, 70, 167-172. [CrossRef]

72. Pararas, E.E.L.; Chen, Z.; Fiering, J.; Mescher, M.J.; Kim, E.S.; McKenna, M.J.; Kujawa, S.G.; Borenstein, J.T.; Sewell, W.F. Kinetics of reciprocating drug delivery to the inner ear. J. Control. Release 2011, 152, 270-277. [CrossRef]

73. Chen, Z.; Kujawa, S.G.; McKenna, M.J.; Fiering, J.O.; Mescher, M.J.; Borenstein, J.T.; Swan, E.E.L.; Sewell, W.F. Inner ear drug delivery via a reciprocating perfusion system in the guinea pig. J. Control. Release 2005, 110, 1-19. [CrossRef] [PubMed]

74. Tandon, V.; Kang, W.S.; Spencer, A.J.; Kim, E.S.; Pararas, E.E.L.; McKenna, M.J.; Kujawa, S.G.; Mescher, M.J.; Fiering, J.; Sewell, W.F.; et al. Microfabricated infuse-withdraw micropump component for an integrated inner-ear drug-delivery platform. Biomed. Microdevices 2015, 17, 37. [CrossRef]

75. Piu, F.; Bishop, K.M. Local Drug Delivery for the Treatment of Neurotology Disorders. Front. Cell. Neurosci. 2019, 13, 238. [CrossRef]

76. Non-invasive drug delivery system for the delivery of protein/peptide using neem gum and its derivatives. Biointerface Res. Appl. Chem. 2020, 10, 5460-5465. [CrossRef]

77. Cervantes, B.; Arana, L.; Murillo-Cuesta, S.; Bruno, M.; Alkorta, I.; Varela-Nieto, I. Solid Lipid Nanoparticles Loaded with Glucocorticoids Protect Auditory Cells from Cisplatin-Induced Ototoxicity. J. Clin. Med. 2019, 8, 1464. [CrossRef] [PubMed]

78. Mohammadian, M.; Moghaddam, A.D.; Sharifan, A.; Dabaghi, P.; Hadi, S. Different forms of whey protein aggregates as curcumin delivery systems: Evaluation of free radical scavenging activity and drug release kinetics. Biointerface Res. Appl. Chem. 2020, 10, 5490-5495. [CrossRef]

79. Ullah, F.; Javed, F.; Khan, A.N.; Kudus, M.H.A.; Jamila, N.; Minhaz, A.; Akil, H.M. Synthesis and surface modification of chitosan built nanohydrogel with antiviral and antimicrobial agent for controlled drug delivery. Biointerface Res. Appl. Chem. 2019, 9, 4439-4445. [CrossRef]

80. Boldyrev, A.; Ziganshin, M.; Mukhametzyanov, T.; Klimovitskii, A.; Lyadov, N.; Gerasimov, A. Formation of microspherical particles of albumin with model drug using spray drying process. Biointerface Res. Appl. Chem. 2019, 9, 4605-4611. [CrossRef]

81. Zindani, D.; Kumar, K. Graphene-based polymeric nano-composites: An introspection into functionalization, processing techniques and biomedical applications. Biointerface Res. Appl. Chem. 2019, 9, 3926-3933. [CrossRef]

82. Leso, V.; Fontana, L.; Ercolano, M.L.; Romano, R.; Iavicoli, I. Opportunities and challenging issues of nanomaterials in otological fields: An occupational health perspective. Nanomedicine 2019, 14, 2613-2629. [CrossRef] [PubMed]

83. Yaqoob, A.A.; Ahmad, H.; Parveen, T.; Ahmad, A.; Oves, M.; Ismail, I.M.I.; Qari, H.A.; Umar, K.; Ibrahim, M.N.M. Recent Advances in Metal Decorated Nanomaterials and Their Various Biological Applications: A Review. Front. Chem. 2020, 8, 341. [CrossRef] [PubMed]

84. Singh, R.P.; Gangadharappa, H.; Mruthunjaya, K. Phospholipids: Unique carriers for drug delivery systems. J. Drug Deliv. Sci. Technol. 2017, 39, 166-179. [CrossRef]

85. Manzano, M.; Vallet-Regí, M. Mesoporous silica nanoparticles for drug delivery. Adv. Funct. Mater. 2020, 30, 1902634. [CrossRef] 
86. Paladini, F.; Pollini, M.; Sannino, A.; Ambrosio, L. Metal-Based Antibacterial Substrates for Biomedical Applications. Biomacromolecules 2015, 16, 1873-1885. [CrossRef]

87. Zou, J.; Hannula, M.; Misra, S.; Feng, H.; Labrador, R.H.; Aula, A.S.; Hyttinen, J.; Pyykkö, I. Micro CT visualization of silver nanoparticles in the middle and inner ear of rat and transportation pathway after transtympanic injection. J. Nanobiotechnol. 2015, 13, 5. [CrossRef] [PubMed]

88. Ziąbka, M.; Menaszek, E.; Tarasiuk, J.; Wroński, S. Biocompatible Nanocomposite Implant with Silver Nanoparticles for OtologyIn Vivo Evaluation. Nanomaterials 2018, 8, 764. [CrossRef] [PubMed]

89. Franci, G.; Falanga, A.; Galdiero, S.; Palomba, L.; Rai, M.; Morelli, G.; Galdiero, M. Silver Nanoparticles as Potential Antibacterial Agents. Molecules 2015, 20, 8856-8874. [CrossRef]

90. Ravishankar Rai, V.; Jamuna Bai, A. Nanoparticles and their potential application as antimicrobials. In Science against Microbial Pathogens: Communicating Current Research and Technological Advances; Mendez-Vilas, A., Ed.; Citeseer: Princeton, NJ, USA, 2011; pp. 197-209.

91. Ahmad, M.A.; Salmiati, S.; Marpongahtun, M.; Salim, M.R.; Lolo, J.A.; Syafiuddin, A. Green Synthesis of Silver Nanoparticles Using Muntingia calabura Leaf Extract and Evaluation of Antibacterial Activities. Biointerface Res. Appl. Chem. 2020, 10, 6253-6261. [CrossRef]

92. Muhsin, T.M.; Hachim, A.K. Mycosynthesis and characterization of silver nanoparticles and their activity against some human pathogenic bacteria. World J. Microbiol. Biotechnol. 2014, 30, 2081-2090. [CrossRef] [PubMed]

93. Bolaños, K.; Kogan, M.J.; Araya, E. Capping gold nanoparticles with albumin to improve their biomedical properties. Int. J. Nanomed. 2019, 14, 6387-6406. [CrossRef]

94. Maleki, M.J.; Pourhassan-Moghaddam, M.; Karimi, A.; Akbarzadeh, A.; Zarghami, N.; Mohammadi, S.A. Synthesis, characterisation, and application of chamomile gold nanoparticles in molecular diagnostics: A new component for PCR kits. Biointerface Res. Appl. Chem. 2019, 9, 4635-4641. [CrossRef]

95. Li, L.; Chao, T.; Brant, J.; O’Malley, B.; Tsourkas, A.; Li, D. Advances in nano-based inner ear delivery systems for the treatment of sensorineural hearing loss. Adv. Drug Deliv. Rev. 2017, 108, 2-12. [CrossRef]

96. Kayyali, M.N.; Brake, L.; Ramsey, A.J.; Wright, A.C.; O’Malley, B.W.; Daqing, L.D. A Novel Nano-approach for Targeted Inner Ear Imaging. J. Nanomed. Nanotechnol. 2017, 8, 1-6. [CrossRef]

97. Dizaj, S.M.; Lotfipour, F.; Barzegar-Jalali, M.; Zarrintan, M.H.; Adibkia, K. Antimicrobial activity of the metals and metal oxide nanoparticles. Mater. Sci. Eng. C 2014, 44, 278-284. [CrossRef]

98. Rodrigues, G.R.; López-Abarrategui, C.; Gómez, I.D.L.S.; Dias, S.C.; Otero-González, A.J.; Franco, O.L. Antimicrobial magnetic nanoparticles based-therapies for controlling infectious diseases. Int. J. Pharm. 2019, 555, 356-367. [CrossRef]

99. Grumezescu, A.M.; Andronescu, E.; Holban, A.M.; Ficai, A.; Ficai, D.; Voicu, G.; Grumezescu, V.; Balaure, P.C.; Chifiriuc, C.M. Water dispersible cross-linked magnetic chitosan beads for increasing the antimicrobial efficiency of aminoglycoside antibiotics. Int. J. Pharm. 2013, 454, 233-240. [CrossRef]

100. Seabra, A.B.; Pelegrino, M.T.; Haddad, P.S. Chapter 24-Antimicrobial Applications of Superparamagnetic Iron Oxide Nanoparticles: Perspectives and Challenges. In Nanostructures for Antimicrobial Therapy; Ficai, A., Grumezescu, A.M., Eds.; Elsevier: Amsterdam, The Netherlands, 2017; pp. 531-550. [CrossRef]

101. Sangaiya, P.; Jayaprakash, R. A Review on Iron Oxide Nanoparticles and Their Biomedical Applications. J. Supercond. Nov. Magn. 2018, 31, 3397-3413. [CrossRef]

102. Narayanan, P.M.; Wilson, W.S.; Abraham, A.T.; Sevanan, M. Synthesis, Characterization, and Antimicrobial Activity of Zinc Oxide Nanoparticles Against Human Pathogens. BioNanoScience 2012, 2, 329-335. [CrossRef]

103. Karimiyan, A.; Najafzadeh, H.; Ghorbanpour, M.; Hekmati-Moghaddam, S.H. Antifungal Effect of Magnesium Oxide, Zinc Oxide, Silicon Oxide and Copper Oxide Nanoparticles Against Candida albicans. Zahedan J. Res. Med. Sci. 2015, 17, e2179. [CrossRef]

104. Swaminathan, M.; Sharma, N.K. Antimicrobial Activity of the engineered nanoparticles used as coating agents. In Handbook of Ecomaterials; Springer International Publishing: Cham, Switzerland, 2019; pp. 549-563.

105. Fathima, J.B.; Pugazhendhi, A.; Venis, R. Synthesis and characterization of $\mathrm{ZrO} 2$ nanoparticles-antimicrobial activity and their prospective role in dental care. Microb. Pathog. 2017, 110, 245-251. [CrossRef]

106. Maniu, A.A.; Perde-Schrepler, M.; Fischer-Fodor, E.; Florea, A.; Chis, G.S.; Roman, A.I. Metallic Nanoparticles in Otology. In Proceedings of the 6th Latin American Congress on Biomedical Engineering (CLAIB 2014), Paraná, Argentina, 29-31 October 2014; Springer Science and Business Media LLC: Cham, Switzerland, 2019; Volume 106, pp. 305-310.

107. Ficanha, A.M.M.; Antunes, A.; Oro, C.E.D.; Dallago, R.M.; Mignoni, M.L. Immobilization of Candida antarctica B (CALB) in Silica Aerogel: Morphological Characteristics and Stability. Biointerface Res. Appl. Chem. 2020, 10, 6744-6756. [CrossRef]

108. Chircov, C.; Spoială, A.; Păun, C.; Crăciun, L.; Ficai, D.; Ficai, A.; Andronescu, E.; Turculet, S.C. Mesoporous Silica Platforms with Potential Applications in Release and Adsorption of Active Agents. Molecules 2020, 25, 3814. [CrossRef] [PubMed]

109. Bernardos, A.; Piacenza, E.; Sancenón, F.; Hamidi, M.; Maleki, A.; Turner, R.J.; Martínez-Máñez, R. Mesoporous Silica-Based Materials with Bactericidal Properties. Small 2019, 15, e1900669. [CrossRef] [PubMed]

110. Selvarajan, V.; Obuobi, S.; Ee, P.L.R. Silica Nanoparticles-A Versatile Tool for the Treatment of Bacterial Infections. Front. Chem. 2020, 8, 602. [CrossRef]

111. Magnetic-silica nanoshell for extraction of fungal genomic DNA from Rhizopus oryzae. Biointerface Res. Appl. Chem. 2020, 10, 4972-4976. [CrossRef] 
112. Schmidt, N.; Schulze, J.; Warwas, D.P.; Ehlert, N.; Lenarz, T.; Warnecke, A.; Behrens, P. Long-term delivery of brain-derived neurotrophic factor (BDNF) from nanoporous silica nanoparticles improves the survival of spiral ganglion neurons in vitro. PLoS ONE 2018, 13, e0194778. [CrossRef] [PubMed]

113. Javadhesari, S.M.; Alipour, S.; Akbarpour, M. Effects of SiC nanoparticles on synthesis and antimicrobial activity of TiCu nanocrystalline powder. Ceram. Int. 2020, 46, 114-120. [CrossRef]

114. Lemraski, E.G.; Tahmasebi, Z.; Valadbeigi, T.; Hajjami, M. Incorporation of Iron Nanoparticles into Silicon Carbide Nanoparticles as Novel Antimicrobial Bimetallic Nanoparticles. Silicon 2018, 11, 857-867. [CrossRef]

115. Baig, U.; Gondal, M.; Ansari, M.; Akhtar, S. Facile synthesis, characterization and antibacterial activity of nanostructured palladium loaded silicon carbide. Ceram. Int. 2018, 44, 16908-16914. [CrossRef]

116. Pezzotti, G. Silicon Nitride: A Bioceramic with a Gift. ACS Appl. Mater. Interfaces 2019, 11, 26619-26636. [CrossRef] [PubMed]

117. Al-Garah, N.H.; Rashid, F.L.; Hadi, A.; Hashim, A. Synthesis and Characterization of Novel (Organic-Inorganic) Nanofluids for Antibacterial, Antifungal and Heat Transfer Applications. J. Bionanosci. 2018, 12, 336-340. [CrossRef]

118. Shah, A.A.; Khan, A.; Dwivedi, S.; Musarrat, J.; Azam, A. Antibacterial and Antibiofilm Activity of Barium Titanate Nanoparticles. Mater. Lett. 2018, 229, 130-133. [CrossRef]

119. Roy, S.; Glueckert, R.; Johnston, A.H.; Perrier, T.; Bitsche, M.; Newman, T.A.; Saulnier, P.; Schrott-Fischer, A. Strategies for drug delivery to the human inner ear by multifunctional nanoparticles. Nanomedicine 2012, 7, 55-63. [CrossRef]

120. Gao, G.; Liu, Y.; Zhou, C.-H.; Jiang, P.; Sun, J.J. Solid Lipid Nanoparticles Loaded with Edaravone for Inner Ear Protection After Noise Exposure. Chin. Med. J. 2015, 128, 203-209. [CrossRef]

121. Mukherjee, S.; Ray, S.; Thakur, R.S. Solid lipid nanoparticles: A modern formulation approach in drug delivery system. Indian J. Pharm. Sci. 2009, 71, 349-358. [CrossRef]

122. Mishra, V.; Bansal, K.K.; Verma, A.; Yadav, N.; Thakur, S.; Sudhakar, K.; Rosenholm, J.M. Solid lipid nanoparticles: Emerging colloidal nano drug delivery systems. Pharmaceutics 2018, 10, 191. [CrossRef]

123. Wang, N.; Gao, X.; Li, M.; Li, Y.; Sun, M. Use of Solid Lipid Nanoparticles for the Treatment of Acute Acoustic Stress-Induced Cochlea Damage. J. Nanosci. Nanotechnol. 2020, 20, 7412-7418. [CrossRef] [PubMed]

124. González-Paredes, A.; Sitia, L.; Ruyra, A.; Morris, C.J.; Wheeler, G.N.; McArthur, M.; Gasco, P. Solid lipid nanoparticles for the delivery of anti-microbial oligonucleotides. Eur. J. Pharm. Biopharm. 2019, 134, 166-177. [CrossRef]

125. Pyykkö, I.; Zou, J.; Zhang, Y.; Zhang, W.; Feng, H.; Kinnunen, P. Nanoparticle based inner ear therapy. World J. Otorhinolaryngol. 2013, 3, 114-133. [CrossRef]

126. Mohammadian, F.; Eatemadi, A.; Daraee, H. Inner ear drug delivery using liposomes. Cell. Mol. Biol. 2017, 63, 28-33. [CrossRef]

127. Srinivasan, M.; Rajabi, M.; Mousa, S.A. Multifunctional Nanomaterials and Their Applications in Drug Delivery and Cancer Therapy. Nanomaterials 2015, 5, 1690-1703. [CrossRef]

128. Abolaban, F.; Djouider, F. Multifunctional Nanoparticle Platforms for Biomedical Applica-Tions: A Review. Dig. J. Nanomater. Biostruct. 2020, 15, 649-661.

129. Lam, S.J.; Wong, E.; Boyer, C.; Qiao, G.G. Antimicrobial polymeric nanoparticles. Prog. Polym. Sci. 2018, 76, 40-64. [CrossRef]

130. Ding, S.; Xie, S.; Chen, W.; Wen, L.; Wang, J.; Yang, F.; Chen, G. Is oval window transport a royal gate for nanoparticle delivery to vestibule in the inner ear? Eur. J. Pharm. Sci. 2019, 126, 11-22. [CrossRef]

131. Tiplea, R.E.; Lemnaru, G.-M.; Trușcă, R.D.; Holban, A.; Kaya, M.G.A.; Dragu, L.D.; Ficai, D.; Ficai, A.; Bleotu, C. Antimicrobial Films based on Chitosan, Collagen, and ZnO for Skin Tissue Regeneration. Biointerface Res. Appl. Chem. 2020, 11, 11985-11995. [CrossRef]

132. Dash, M.; Chiellini, F.; Ottenbrite, R. Chitosan-A versatile semi-synthetic polymer in biomedical applications. Prog. Polym. Sci. 2011, 36, 981-1014. [CrossRef]

133. Tawfik, T.M.; El-Masry, A.M.A. Preparation of Chitosan Nanoparticles and its Utilization as Novel Powerful Enhancer for Both Dyeing Properties and Antimicrobial Activity of Cotton Fabrics. Biointerface Res. Appl. Chem. 2021, 11, 13652-13666. [CrossRef]

134. Lajud, S.A.; Nagda, D.A.; Qiao, P.; Tanaka, N.; Civantos, A.; Gu, R.; Cheng, Z.; Tsourkas, A.; O’Malley, B.W.; Li, D. A Novel Chitosan-Hydrogel-Based Nanoparticle Delivery System for Local Inner Ear Application. Otol. Neurotol. 2015, 36, 341-347. [CrossRef] [PubMed]

135. Banerjee, M.; Mallick, S.; Paul, A.; Chattopadhyay, A.; Ghosh, S.S. Heightened Reactive Oxygen Species Generation in the Antimicrobial Activity of a Three Component Iodinated Chitosan-Silver Nanoparticle Composite. Langmuir 2010, 26, 5901-5908. [CrossRef]

136. Zhao, W.; Gu, J.; Zhang, L.; Chen, A.H.; Shi, J. Fabrication of Uniform Magnetic Nanocomposite Spheres with a Magnetic Core/Mesoporous Silica Shell Structure. J. Am. Chem. Soc. 2005, 127, 8916-8917. [CrossRef]

137. Namazi, H.; Rakhshaei, R.; Hamishehkar, H.; Kafil, H.S. Antibiotic loaded carboxymethylcellulose/MCM-41 nanocomposite hydrogel films as potential wound dressing. Int. J. Biol. Macromol. 2016, 85, 327-334. [CrossRef]

138. Zhang, Y.; Zhang, W.; Löbler, M.; Schmitz, K.-P.; Saulnier, P.; Perrier, T.; Pyykkö, I.; Zou, J. Inner ear biocompatibility of lipid nanocapsules after round window membrane application. Int. J. Pharm. 2011, 404, 211-219. [CrossRef]

139. Zhou, H.; Ma, X.; Liu, Y.; Dong, L.; Luo, Y.; Zhu, G.; Qian, X.; Chen, J.; Lu, L.; Wang, J.; et al. Linear polyethylenimine-plasmid DNA nanoparticles are ototoxic to the cultured sensory epithelium of neonatal mice. Mol. Med. Rep. 2015, 11, 4381-4388 [CrossRef] [PubMed] 
140. Nguyen, Y.; Celerier, C.; Pszczolinski, R.; Claver, J.; Blank, U.; Ferrary, E.; Sterkers, O. Superparamagnetic nanoparticles as vectors for inner ear treatments: Driving and toxicity evaluation. Acta Oto-Laryngol. 2016, 136, 402-408. [CrossRef] [PubMed]

141. Schneider, T.; Westermann, M.; Glei, M. In vitro uptake and toxicity studies of metal nanoparticles and metal oxide nanoparticles in human HT29 cells. Arch. Toxicol. 2017, 91, 3517-3527. [CrossRef]

142. Wen, X.; Ding, S.; Cai, H.; Wang, J.; Wen, L.; Yang, F.; Chen, G. Nanomedicine strategy for optimizing delivery to outer hair cells by surface-modified poly(lactic/glycolic acid) nanoparticles with hydrophilic molecules. Int. J. Nanomed. 2016, 11, 5959-5969. [CrossRef] [PubMed]

143. Musazzi, U.M.; Youm, I.; Murowchick, J.B.; Ezoulin, M.J.; Youan, B.-B.C. Resveratrol-loaded nanocarriers: Formulation, optimization, characterization and in vitro toxicity on cochlear cells. Colloids Surfaces B Biointerfaces 2014, 118, 234-242. [CrossRef] [PubMed]

144. Sun, C.; Wang, X.; Chen, D.; Lin, X.; Yu, D.; Wu, H. Dexamethasone loaded nanoparticles exert protective effects against Cisplatin-induced hearing loss by systemic administration. Neurosci. Lett. 2016, 619, 142-148. [CrossRef]

145. Miwa, T.; Saito, H.; Akita, H. Lipid nanoparticles-encapsulated brain-derived neurotrophic factor mRNA delivered through the round window niche in the cochleae of guinea pigs. Exp. Brain Res. 2021, 239, 425-433. [CrossRef] [PubMed] 